\title{
The avifauna of the Beni Biological Station, Bolivia
}

\author{
ROBIN C. BRACE, JON HORNBUCKLE and JAMES $W$. \\ PEARCE-HIGGINS
}

\section{Summary}

An annotated compendium of all those bird species known to have occurred in the lowland "Man and Biosphere" Beni Biological Station (B.B.S.) reserve is provided. Previous checklists are reviewed, together with sightings accumulated over the 19921995 period during which approximately 70 new species have been added to the reserve inventory, bringing the total to 478 . Occurrence across the 12 delineated habitats, relative abundance and sighting documentation are given for each species. The avifauna of the B.B.S. is mixed biogeographically; in addition to a substantial component of lowland birds widespread throughout South America, it is composed of Amazonian, cerrado and chaco elements also. Representation from the Bolivian Yungas is minimal. Significantly, no less than four threatened and 15 near-threatened species have occurred, including the little known Bolivian endemic Unicoloured Thrush Turdus haplochrous, and the enigmatic White-winged Nightjar Caprimulgus candicans, known until recently only from Emas National Park (Brazil). Short accounts are provided detailing records of all of these species. Birds of the reserve core, consisting largely of humid tropical forest formations inundated during the austral summer, appear not to be subjected currently to any serious environmental degradation, although some subsistence clearance by Chimane Indians in the northern reaches of the reserve gives some cause for concern. Of much greater import, however, are changes occurring outside the confines of the B.B.S. These include increasing urbanization immediately to the west (and associated road upgrading) and forest fragmentation to the south brought about by logging. The latter is especially worrying because linkage of the B.B.S. forest block to surrounding forest is already physically tenuous, and therefore it is imperative that future logging activities be geared to minimize isolation occurring and the damaging restriction of gene flow. Monitoring in rainforest immediately south of the reserve should become routine to warn of putative arifaunal impoverishments. Extensive surveying of the 2,500-ha El Porvenir éstancia (savanna and related forest islands) due to be assimilated shortly into the B.B.S., which constitutes less than $2 \%$ of the area under consideration, has shown that it is used by no less than three threatened and up to nine near-threatened species. In the absence of data relating to other savanna areas $(c, 15 \%)$ at present, the exact status of each species at the B.B.S. remains imprecise and begs for further research to be undertaken. Unfortunately, present management of the El Porvenir savanna is not conducive to the long-term maximization of populations of these species, several of which have local strongholds in this part of Beni. We recommend that the current policy of cattle ranching adopted by this éstancia should cease or be reduced dramatically, to minimize grazing and trampling damage, and that measures should be taken to reduce incursions of fires started wilfully in neighbouring properties. The Academia Nacional de Ciencias de Bolivia, which administers the reserve, should be encouraged to safeguard and enhance the savanna complement further by ensuring that the impending ratification of El 
Porvenir proceeds as quickly as possible, and by purchasing additional tracts of land to the south of the present southern reserve boundary, where feasible. Such actions should not only secure the future of the biota of the savanna habitat within the B.B.S. but also should ameliorate the degree of isolation which has occurred already by preserving the "curiches" (former river beds) and forest islands which act as access corridors for forest-dwelling and other birds.

\section{Introduction}

Bolivia has the richest avifauna of any land-locked country in the world but until comparatively recently documentation of this avifauna has lagged well behind that of most other Neotropical countries. The deserved insurgence of interest in the birds of Bolivia in the 1980 s resulted in the publication of a much-needed modern checklist (Remsen and Traylor 1989), whose appearance was in turn responsible for catalysing a further acceleration of avian chronicling. To date, over 1360 species have been recorded (Arribas et al. 1995). Quite naturally, most attention has focused on the forested Andean slopes, where endemism is highest (Remsen and Parker 1995), meriting the recognition of five "Endemic Bird Areas" (E.B.A.s) (Bibby et al. 1992a). However, much of the country lies at low altitude, with Amazonian rainforest located to the north and xerophytic chaco (scrub-thorn) to the south, interposed between which is a complex mix of forest, savanna and grassland. Although embracing one E.B.A. only, the lowlands are inhabited by no less than 10 out of the 27 threatened birds listed for Bolivia by Collar et al. (1994), including four endemics, of which the highly localized Blue-throated Macaw Ara glaucogularis deserves specific mention (Jordan and Munn 1993, Brace et al. 1995c). Wege and Long (1995) described to lowland Key Areas, of which the Beni Biological Station (B.B.S.) (Estación Biológica del Beni), the subject of this paper, is one.

The $\sim 160$, o0o-ha (R. Urioste pers. comm.) B.B.S. (IUCN category I) (IUCN 1992) was afforded legally protected status by governmental decree in 1982, and became a UNESCO "Man and Biosphere" reserve in 1986. It encompasses seasonally wet tropical forest and savanna, swamps and lagoons. Of the 478 species recognized here as having occurred at the B.B.S., four are threatened: Crowned Eagle Harpyhaliaetus coronatus, White-winged Nightjar Caprimulgus candicans, Military Macaw Ara militaris and Black-masked Finch Coryphaspiza melanotis (Collar et al. 1994). Unicoloured Thrush Turdus haplochrous and Grey-and-chestnut (Rufous-rumped) Seedeater Sporophila hypochroma, regarded formerly as threatened (Collar et al. 1992, see Wege and Long 1995), are considered now to be near-threatened.

Cabot et al. (1986) produced the first avian checklist of the B.B.S., which included about 200 species. Subsequent surveys increased the inventory to approximately 320 species (Flores 1988, S. L. Hilty unpubl. data, Rocha 1988, 1990). The reserve management plan (Miranda et al. 1991), incorporating later observations (e.g. Parker et al. 1991), raised the total to over 4 oo (but overlooked several species reported in the earlier lists). Since 1992 there has been a presence during the austral winter of personnel from the University of Nottingham, U.K., which has amplified considerably our knowledge of this avifauna. Sightings by 
White et al. (1993) in 1992 (R.C.B. present) made during International Council of Bird Preservation (ICBP) expeditionary survey work (July to October) included visits to two localities in the northern reaches of the reserve, which had been unexplored hitherto. As a consequence 52 species were added (as recognized here), of which the Unicoloured Thrush, a little known endemic, was perhaps the most significant find. R.C.B. visited for two weeks in August 1993 and was present, with J.H. and Earthwatch volunteer groups (Brace et al. 1995a), for six weeks in both 1994 and 1995; J.W.P.-H. joined us in 1995. Observations over the 1993-1995 period have concentrated principally on islands of forest set in savanna close to the headquarters at El Porvenir, although contiguous rainforest was explored as well. Although lying outside the current reserve boundary at the present time, records from this well-worked area are incorporated since official inclusion is impending (C. Miranda verbally 1996).

The purpose of this paper is to provide the first detailed appraisal of the reserve's avifauna. It highlights additional information acquired on the presence of threatened and near-threatened species during the 1992-1995 period. That considerable attention has been paid to savanna-based species is deemed of great merit because grasslands are being lost rapidly in South America (see Goriup 1988), affecting adversely such birds as Ocellated Crake Micropygia schomburgkii, Sharp-tailed Grass-tyrant Culicioora caudacuta, Black-masked Finch and Dark-throated Seedeater Sporophila ruficollis, all of which occur at the B.B.S. It is hoped that the availabity oi such a compendium will serve to draw attention to the especially rich biodiversity of one of the most publicized conservation units in Bolivia today, whose administrative body, the Academia Nacional de Ciencias de Bolivia, has been a major contributor to policy development of protected areas within the country.

Beni Biological Station (Estación Biológica del Beni) (B.B.S.)

\section{Location, topography and climate}

The B.B.S. is located within the provinces of Ballivián and Yacuma in the Benian lowlands, and lies $180 \mathrm{~km}$ to the west of Trinidad, the departmental capital, and $50 \mathrm{~km}$ to the east of San Borja (Figure 1). The core area, at an altitude of 190 to $220 \mathrm{~m}$, measures roughly 80 by $30 \mathrm{~km}, \mathrm{c} .70 \%$ of which is covered by a variety of forest types (Figure 2). These include evergreen terra firme and open deciduous woodland (Miranda et al. 1991) but October to April inundation ensures that humid seasonal categories dominate. The Manique and Curiraba rivers form the northern and southern limits respectively of the reserve core. The former, a "white water" river, is responsible for much of the seasonal inundation. Its past meander dynamics have created a rich successional mix, which includes riparian and swamp forests. To the south of the Curiraba (a "black water" river) lies a block of savanna (also seasonally flooded) in which are dotted numerous forest islands ("islas des bosques"), ranging from a fraction of a hectare to several hectares in size; small patches of savanna are located too between the Aguas Negras and Curiraba rivers. The southern fringe of this savanna block is demarcated by the Trinidad to San Borja road, whose 


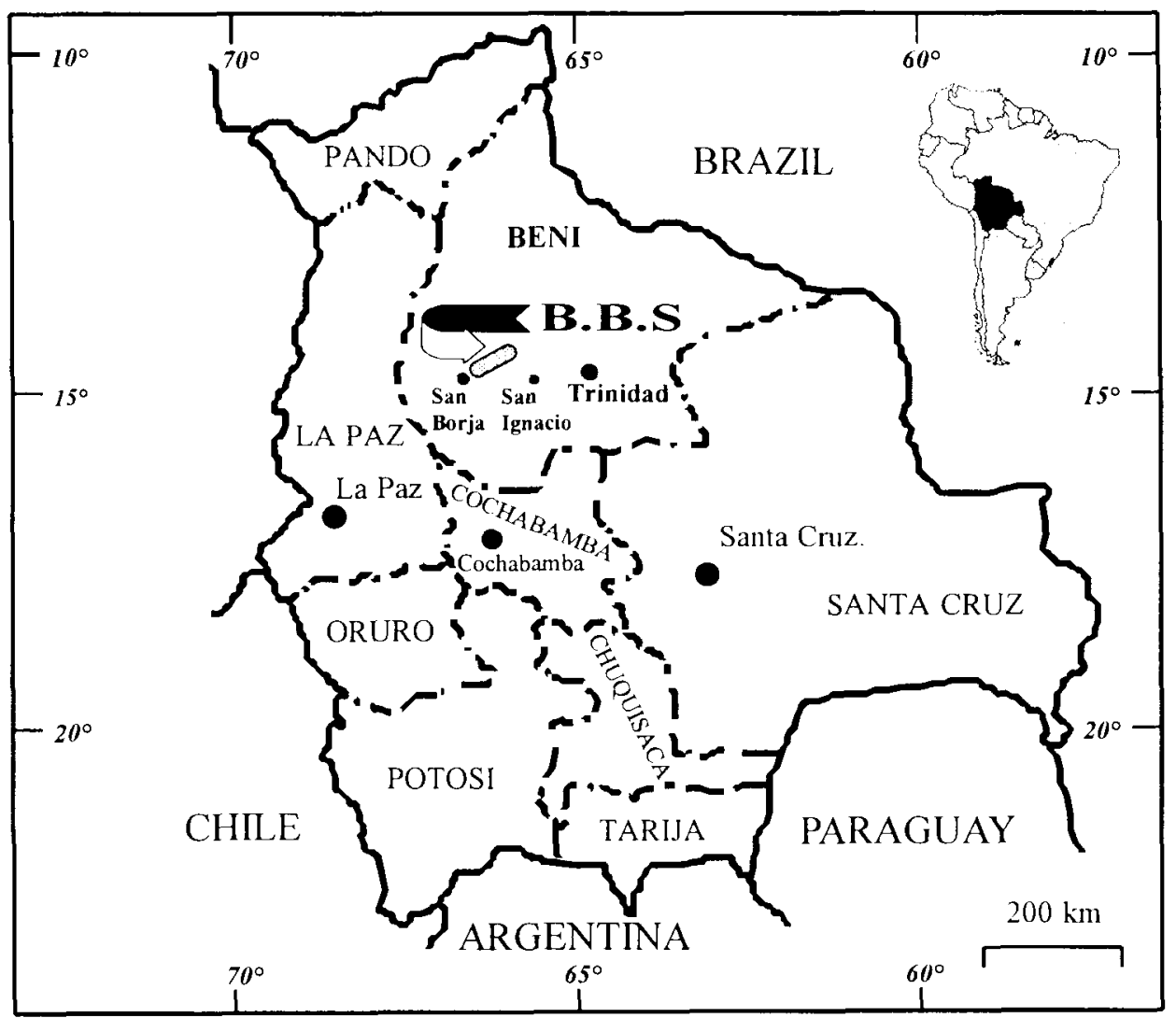

Figure 1. The location of the Beni Biological Station (B.B.S.). Administrative departments of Bolivia are shown, together with some cities and towns. Borders of contiguous countries are indicated, and the focal position of Bolivia within South America highlighted in the insert.

construction in 1977 was responsible for some forest fragmentation (e.g. Florida fragment located adjacent to El Porvenir). It is to be noted, however, that a much greater area of savanna is present in the eastern sector of the reserve.

The 2,500-ha El Porvenir (PVR) éstancia $\left(14^{\circ} 50^{\prime} \mathrm{S} 66^{\circ} 17^{\prime} \mathrm{W}\right)$ provides a corridor stretching from the reserve to this road (see Figure 3); the southernmost third of the PVR savanna is grazed by cattle. To reach the forest camps, El Trapiche (TPC) and Pascana (PSC), the only readily accessible sites for forest-based research, it is necessary to cross a corner of the El Triunfo (TRF) éstancia. When the B.B.S. was established, unofficial conservation "buffer zones" were recognized with a view to future incorporation and ratification. These areas included the PVR éstancia and adjacent land separating the local road and the Río Matos, and terrain immediately north of the Rio Manique.

As a "Man and Biosphere" reserve, the welfare of the 1,200+ indigenous Chimane Indians living within the B.B.S. is catered for, and indeed the reserve forms one component of a larger area covered by the Chimane Ecosystem Programme (Conservation International 1988) designed to promote sustainability, 


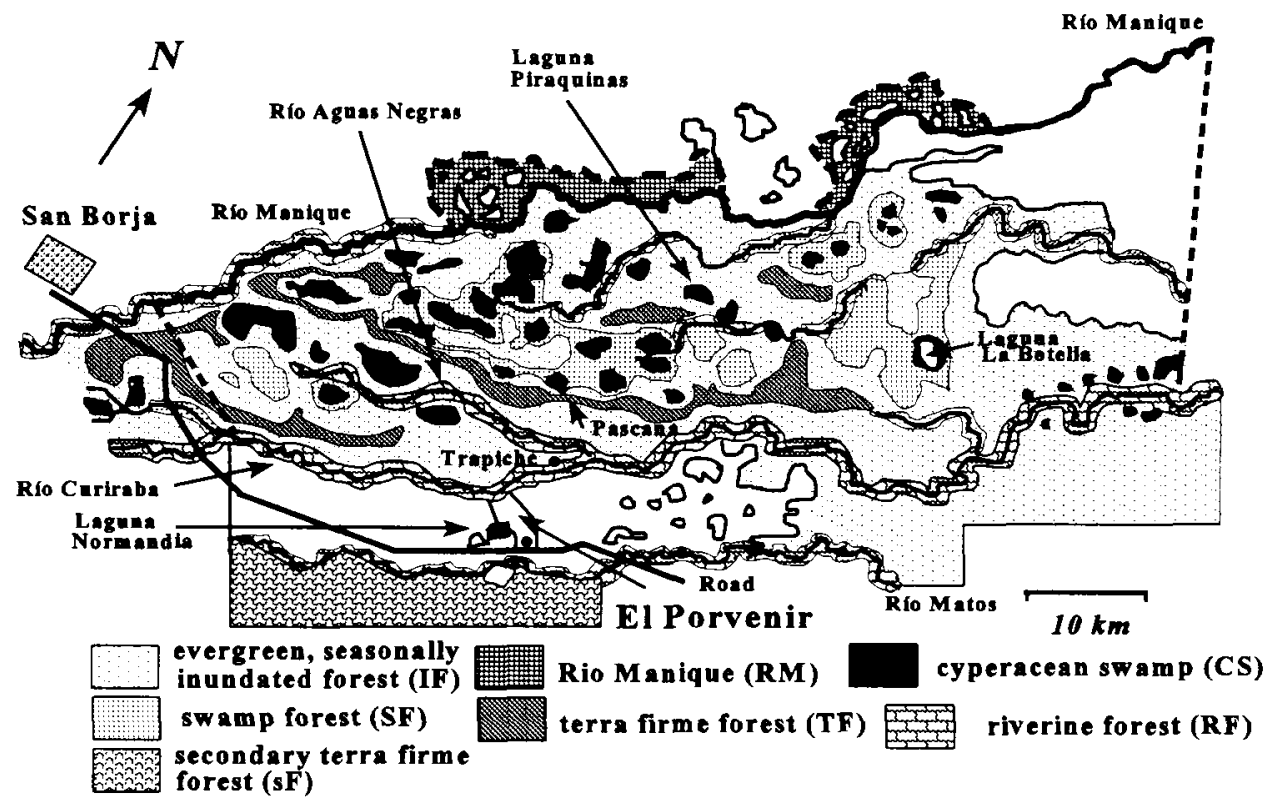

Figure 2. Current extent of, and predominant vegetational zones, within the Beni Biological Station (B.B.S.). To the south-west and north-east the limits of the B.B.S. are demarcated by dashed lines. To the north the reserve is delimited by the Río Manique (dashed line in part) and to the south - currently - by the Rio Curiraba. Shown also is the area to the south of the latter where the El Porvenir éstancia - soon to be incorporated into the B.B.S. - is located. Unstippled areas in the east, and adjacent to the road depicted, designate savanna; to the east of El Porvenir (only), a representative selection of savanna-based forest fragments/islands is depicted. Based on maps in Miranda et al. (1991).

self-determination, training and environmental awareness. One sector of this, which lies south of Totaizal and from which mahogany and cedar are extracted, is given over to "permament production" forest (Dudley 1992).

The B.B.S. experiences a mean temperature of $26^{\circ} \mathrm{C}$ (range $11-38^{\circ} \mathrm{C}$ ) and is subject to a mean humidity of $76 \%$ (range 60-90\%) (Miranda et al. 1991). Annual precipitation averages $1800 \mathrm{~mm}$, with rain during the wet season (November to May) emanating from Amazonia. Outside this season, rain is associated with periodic ( $c a$ 2-3 week intervals) cold fronts ("surazos") moving northwards from Argentina.

\section{Biogeography and habitat classification}

The inventory of birds at the B.B.S. is extensive since the reserve combines depauperate Amazonian forest, cerrado and chaco avifaunal elements.

Miranda et al. (1991) provided a detailed listing of major macro-vegetational types/habitats (19 categories) recognised at the B.B.S. and we categorize bird distributions accordingly. Below we describe 12 categories including several alluded to by Flores (1988). Trees typical of each habitat are mentioned where appropriate (for detailed information see Killeen et al. 1993). Local names of 


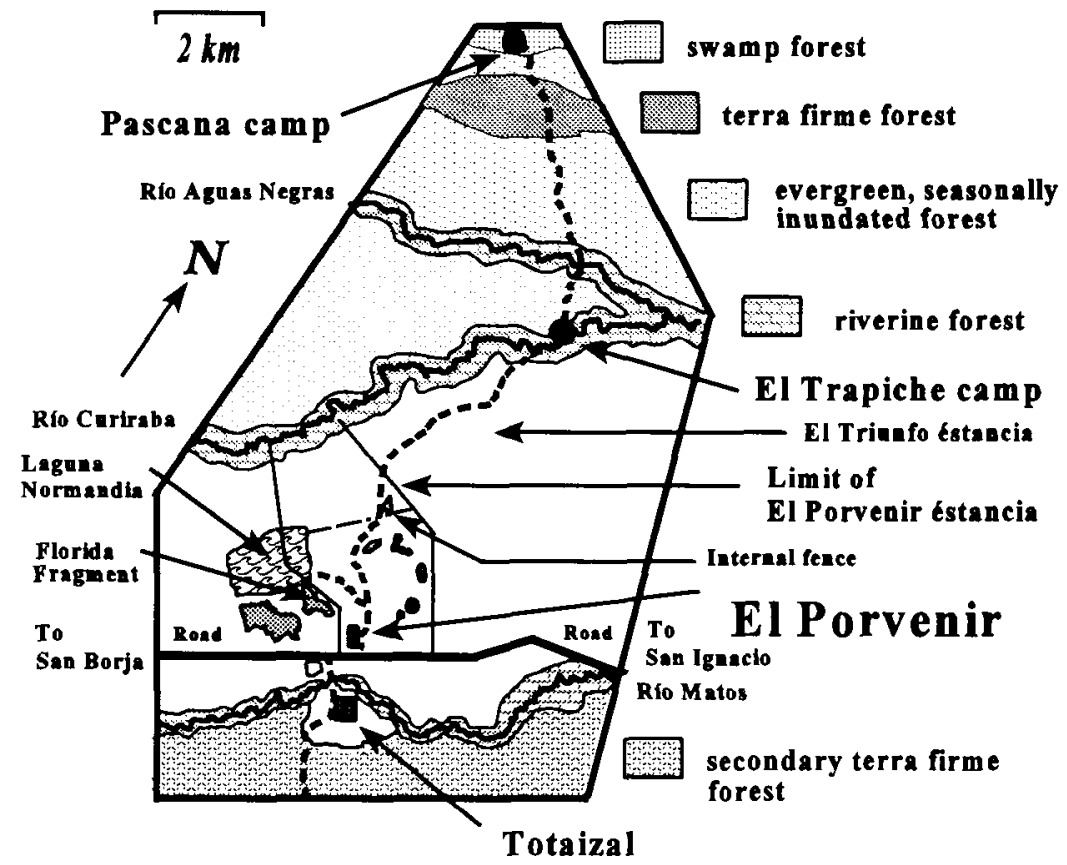

Figure 3. Study areas and associated terrains in the vicinity of the El Porvenir headquarters. Tracks linking El Porvenir with forest camps in the north and extending south from Totaizal into secondary terra firme forest, are indicated by dashed lines. The former in particular crosses open savanna (unstippled) in which lie many forest islands, some of which are illustrated, and two forest fragments including Florida.

especially conspicuous elements are included. The distribution of these habitats can be appreciated by reference to Figure 2 from which the relative extents of seven predominant categories, given below as percentages (somewhat artificially totalling $100 \%$ ), have been derived employing a digitizer; abbreviations listed are those used in Appendix 1.

TF Evergreen terra firme (primary) forest (8\%): Ceiba pentandra (kapok) (Bombacaceae), Ficus spp. (Moraceae), Hevea brasilensis (Euphorbiaceae), Swietenia macrophylla (Meliaceae).

IF Evergreen, seasonally inundated forest (várzea) (46\%): Ficus spp. (Moraceae), Ceiba spp. (Bombacaceae), Astrocaryum macrocalyx, Scheelea princeps (motacú palm) (Palmaceae).

RF Riverine (riparian) forest (8\%): Salix humboldtiana (Salicaceae), Cecropia spp. (Moraceae), Rheedia spp. (Guttiferaceae).

SF Swamp forest (9\%): lianas including Ficus spp. (Moraceae), Bactris spp. (Palmaceae), Calycophyllum spruceanum (Rubiaceae).

sF Secondary terra firme forest (largely "cut-over").

DF Open mixed deciduous forest: Curatella americana (Dilleneaceae), Tabebuia spp. (tajibo) (Bignoniaceae). 
FI Forest islands ( $<1$ to $c .5$ ha): Guazuma ulmifolia (coco) (Sterculiaceae), Tabebuia impetiginosa, T. chrysantha (Bignoniaceae), Acrocomia totai (totaí palm), Scheelea princeps, (Palmaceae).

CH Chaco-like thorny scrub: Acacia sp. (Mimosoideae); Copernicia alba (Palmaceae).

SV Savanna (largely seasonally inundated) (18\% total - El Porvenir éstancia 2\%, other 16\%): Andropogon bicornis (Graminaceae), Curatella americana (Dillenaceae), Tabebuia aurea, T. chrysantha (Bignoniaceae).

CR "Curichis", seasonally wet, well vegetated (contiguous trees included), meandering, former river beds, usually with cyperacean components, and artificially created roadside drains/pools.

CS Cyperacean swamps, and cyperacean fringes (including scattered trees) of lagoons (5\%): Rynchospora trispidata, Cyperus giganteus (Cyperaceae), and associated open water.

RM Río Manique (including sandy beaches) (6\%).

Sections of the PVR savanna are burnt deliberately during the August-September period to stimulate the growth of grass for grazing; this also promotes reproduction of many herbaceous species (Killeen et al. 1990). The invasion of fires started in neighbouring éstancias is not uncommon during these months, resulting in large areas being affected. Denevan (1966) suggested that the majority of the forest islands, which are slightly elevated (predominantly $<1 \mathrm{~m}$ ), owe their origins to human activities, but whilst abundant artefacts indicate past human occupancy (e.g. Majeño culture from 1,200 BC to $800 \mathrm{AD}$ ), other evidence favours most islands having been formed naturally (Erlichson and Faldin unpubl. data). Biogeographically, the flora of these islands is mixed (Killeen et al. 1993); correspondingly, their avifaunal compositions are distinct from that of adjacent rainforest (Brace et al. 1995b, unpublished).

\section{Particular study locations/areas}

El Porcenir éstancia (Figure 3) White et al. (1993) examined this region for two weeks in 1992; expeditionary surveys led by Brace in 1994 and 1995 extended over 15 weeks in total. El Porvenir itself is the site of a former forest island, alongside which is a "curichi" attractive to waterbirds. Part of the Laguna Normandia, which has a dense, swampy cyperacean fringe with some emergent trees and bushes, is encapsulated by this éstancia.

Forest camps approached from El Porwenir (Figure 3) Just north (c. $250 \mathrm{~m}$ ) of the Curiraba (and c. $600 \mathrm{~m}$ distant from the northern fringe of the savanna) lies TPC, where White's team stayed for one week in 1992, and to which Brace and colleagues paid six visits over the 1993-1995 period (total of approximately two weeks in residence). The low $(<15 \mathrm{~m})$ forest here is riverine (seasonally inundated) and dominated by palms; tangled bushes accompany the river bed itself but elsewhere undergrowth is not dense. The second camp, PSC, some $6 \mathrm{~km}$ further into the forest, lies alongside a small "black-water" lagoon sur- 
ounded by higher and denser swamp-forest. From PSC tracks continue northwest and south-east. The route linking these two camps traverses the Aguas Negras and some terra firme forest. White's group spent 1o days at PSC. Although Brace's teams explored the TPC to PSC track to just beyond the Aguas Negras on many occasions, they visited PSC just once. This part of the reserve was visited by Rocha and Peñaranda (1992) to study the feeding ecology of four species of woodcreeper (Dendrocolaptidae).

Forest camps reached by boat along the Rio Manique Two such camps were used in 1992 by White's team. One week was spent at Turtle camp (TRC) on the northern bank ( $\mathrm{Ca} 35 \mathrm{~km}$ from San Borja), where the strip of disturbed forest with some clearings and a Chimane village gives way quickly to savanna. Here, immediately south of riverine forest fringing the southern bank, is mature high canopy, terra firme forest, with a palm-dominated understorey and relatively open shrub layer; some bamboo was present. Final camp (FNC), the second location used (for two weeks), is in the north-eastern extremity of the reserve, on the south bank of the Manique, from which tracks lead into high (to $30 \mathrm{~m}$ ) riverine and swamp forest (but quite open in places) giving access to an area of pampas-like savanna.

Much of the interior of the vast B.B.S. forest block, which is historically relatively young due to past changes in the course of the Manique, is inaccessible. Although large areas are flooded during the austral summer, a season with which we are unfamiliar, thus making access difficult, the raised water level of the Curiraba allows additional areas to be reached by boat.

\section{Study methods}

Although many sightings from 1992 onwards (White et al. 1993, R.C.B. et al. unpubl.) were made during censuses employing standard quantitative counting techniques, including timed line transects (walks), and square and point counts (Karr 1981, Bibby et al. 1992), observational methods have differed according to habitat and need. This point, together with the fact that the resulting species list (see Appendix 1) has been compiled principally from observations made by many people not engaged overtly in quantitative work, has meant that the presentation of comparative abundance data is not feasible. Nevertheless, using data from Miranda et al. (1991) as a guideline, we have attempted to provide a coarse abundance rating to indicate the status of species (within suitable habitat or habitats).

Mist-netting was undertaken to facilitate both the detection of cryptic species and species identification (e.g. Synallaxis spinetails). White and colleagues trapped birds on a routine basis in 1992 at the five principal locations visited. In 1994 and 1995, J.H. ringed and photographed birds mist-netted at the following locations: (i) PVR (open savanna), (ii) PVR (scrub), (iii) PVR (range of forest islands 1-5.5 ha), (iv) TPC (adjacent to the Río Curiraba riverbed), (v) TPC (forest $c .300-500 \mathrm{~m}$ north of the campsite). All those species inspected in the hand over the 1992-1995 period, are denoted (Trap). Tape-recording and the playback of vocalizations were employed to lure unrecognized callers into view. Prerecorded tapes were used to elicit calls, especially from cryptic species. 


\section{Systematic list and species accounts}

\section{Introductory comments}

Ordering within the full species list provided in Appendix 1 is conservative and follows primarily Clements (1991). Rearrangements of suboscines at family and subfamily ranks, introduced by Ridgely and Tudor (1994), have not been incorporated here, but a number of recent taxonomic changes at the species level which follow Monroe and Sibley (1993) have been adopted.

All species regarded as threatened (THR) or near-threatened (NT) (Collar et al. 1994) receive treatment in the accounts below. Species recorded for the first time at the B.B.S. by White et al. (1993), or subsequently by us will be dealt with in a separate paper (Brace et al. unpubl.). Initial chronicling of species in previous reserve lists (or other sources) is acknowledged. All those species seen during field studies from 1992 onwards, which were listed previously, are denoted (o); additions are highlighted by giving the year of initial observation.

A total of 16 species listed by other authors have not been included here. Our reasons for omitting these species at this time are given in Appendix 2. Two B.B.S. entries given in Arribas et al. (1995) on the basis of our submissions, are withdrawn here: (1) Sooty-fronted Spinetail S. frontalis, spinetails considered to be this species (R.C.B., J.H. in 1994) have been re-identified as Pale-breasted $S$. hypospodia, a species whose plumage is highly variable (Brace et al. unpubl.); (2) White-winged Black-Tyrant K. atterimus, one Knipolegus seen in 1993, which was assigned to K. atterimus (R.C.B.), is regarded now as Hudson's K. hudsoni. Authors initials appearing in the following species accounts signify personal experience of the species concerned at the B.B.S.

\section{Threatened and near-threatened species accounts}

Greater Rhea Rhea americana (NT) Recorded on an irregular basis in the PVR and TRF savannas (R.C.B., J.H, J.P.-H.). Normally no more than two or three seen together, but a party of six was disturbed from the periphery of a forest island on one occasion (R.C.B.) (22 July 1993). It is pertinent to note that Dott (1984) commented that his sightings in Beni were the first published since those of Gyldenstolpe (1945). The degree of local threat to the species is not known, although it is said to be declining due to annual savanna burning (which coincides with breeding in Beni) and conversion to pasture (S. Stab verbally 1994), as is undoubtedly the case in Argentina (Bucher and Nores 1988). Most authors describe the species in Bolivia as rare (e.g. Remsen 1986, Kratter et al. 1993, Davis 1993).

Orinoco Goose Neochen jubata (NT) One in flight along the Río Manique (3 September 1992) (White et al. 1993) is the only sighting to report but it has been observed previously on wet savanna with short vegetation (Miranda et al. 1991), habitat in which the species occurs elsewhere in Beni (Remsen 1986). Occurs widely in Beni with concentrations (up to 250) known from the Lagunas Beni and Pando, and the Río Yacuma (Scott and Carbonell 1986) but its exact status in Bolivia is uncertain. 
Agami (Chestnut-bellied) Heron Agamia agami (NT) Recorded from riverine forest and swampy areas (Miranda et al. 1991).

Zigzag Heron Zebrilus undulatus (NT) Added to the reserve list in 1992 (I1 August); one was seen by the small lagoon at PSC (White of al. 1993). First recorded in Bolivia (north-east Beni) by Pearson (1975); known only from Beni and Santa Cruz (Arribas et al. 1995).

Crowned Eagle Harpyhaliaetus coronatus (THR - vulnerable) An immature was seen flying low over the Rio Manique near TRC (1 September 1992) and good views obtained of an adult perched in a small tree (Tabebuia aurea) in savanna $2 \mathrm{~km}$ south-west of TPC (27 July 1993) (R.C.B.). Listed first in an early version (1989) of Miranda et al. (1991) (see Rocha 1990, but no further details secured), this predominantly open-country raptor was tabulated as having occurred in a range of habitats in the B.B.S. The few Bolivian reports of this species relate to Beni and Santa Cruz (Collar et al. 1992, Kraiter et al. 1993), though the initial one lacked a specific locality (Remsen and Traylor 1989). Its status in Bolivia is unclear but elsewhere the species is suffering from habitat modification and hunting pressure (Collar et al. 1994).

Crested Eagle Morphnus guianensis (NT) The sole report for the reserve is of an adult seen on 17 September 1992 perched in dense forest at FNC (White et al. 1993). Within Bolivia known only from two other departments: La Paz (Remsen and Parker 1995) and Santa Cruz (Noel Kempff Mercado National Park) (Vasquez unpubl. data, Pearce-Higgins et al. unpubl. data). It is regarded as rare in Bolivia as elsewhere (Collar and Andrew 1988) but its exact status is uncertain.

Harpy Eagle Harpia harpyja (NT) Scarce over dense terra firme forest (Miranda et al. 1991). One was picked up dead in the El Triunfo éstancia in 1995 (S. Stab verbally 1995). The species has been recorded widely from Bolivia (Remsen and Traylor 1989, Davis et al. 1994).

Black-and-white Hawk-Eagle Spizastur melanoleucus (NT) Documented in Cabot et al. (1986), with a sighting $50 \mathrm{~km}$ east of San Borja mentioned in Cabot and Serrano (1986) taken to be the basis for inclusion by Miranda et al. (1991). One was seen at FNC on 16 September 1992 (White et al. 1993). Initia! Bolivian sightings were summarized by Remsen and Ridgely (1980).

Ocellated Crake Micropygia schomburgkii (NT) A small number were heard and disturbed, and one photographed, in a recently burnt area of the PVR savanna, some $2 \mathrm{~km}$ north of El Porvenir during August 1994 (e.g. three on 3 August). Heard only in this savanna in 1995 (R.C.B., J.H.). Prior to these records, this cryptic species was not known from the B.B.S. but it is apparently numerous and widespread in grasslands (both seasonally inundated and well drained) in northern and eastern Bolivia and has been noted as occurring widely between the B.B.S. and San Borja, $50 \mathrm{~km}$ to the west (Parker 1989, Parker et al. 1991). 
Before these observations, it was known in Beni from just one specimen, collected from San Joaquin (Blake 1977).

Military Macaw Ara militaris (THR - vulnerable) The only sighting was of a flock of 15 flying over pampas and forest adjacent to FNC on 17 September 1992 (White ef al. 1993), the first Beni record of this Andean foothill species, known previously from Santa Cruz, Chuquisaca and Tarija (Remsen et al. 1986, Remsen and Traylor 1989). It has been recorded now apparently from La Paz also (Arribas et al. 1995).

White-winged Nightjar Caprimulgus candicans (THR - Critical) A male was collected by hand in open savanna near El Porvenir on 11 September 1987 (Davis and Flores 1994), representing the first record for Bolivia. It is very rare and had been recorded previously this century only from Emas National Park in Brazil (see Collar et al. 1992), some $1500 \mathrm{~km}$ to the east but in 1995 was discovered in the Reserva Natural de Bosque Mbaracayú, Paraguay (Lowen et al. 1996), the first confirmed record for that country. Clearly more information on the status of the species at the B.B.S. is required urgently.

Sharp-tailed Tyrant Culicivora caudacuta (NT) One seen in the PVR savanna on 13 August 1994 (J.H.) was the first B.B.S. record. In 1995, three were noted in the same area, typified by long grass, on both 20 and 28 August (R.C.B., J.W.P.-H.). It occurs locally within open grasslands but is apparently widespread in Beni (Schmitt and Schmitt, 1987, Parker 1989, Parker et al. 1991, Parker and Rocha 1991), with a number of previous sightings relating to areas immediately west of the B.B.S., where family parties were observed. To the east its distribution is presumably continuous through to Brazil; in the Noel Kempff Mercado National Park adjacent to the Brazilian border, it occupies cerrado on the Serranía de Huanchaca (Parker and Bates unpubl. data).

Hudson's Black-Tyrant Knipolegus hudsoni (NT) This winter visitor, whose documented occurrence at the B.B.S. by Cabot et al. (1986) was overlooked subsequently by Rocha (1990) and Miranda et al. (1991), was observed on most days in trees and bushes at woodland and road edges in the vicinity of PVR in 1992 (White et al. 1993). It was noted also in 1993, by R.C.B. (see "Introductory comments" above). A small number was seen (c. 6 maximum) on most days in the same area in both 1994 and 1995 (with, respectively, 11 and 13 individuals being mist-netted) (R.C.B, J.H., J.W.P.-H.). Re-trapping substantiated the impression gained that certain individuals were resident in particular forest islands (two birds: trapping intervals of five and eight days) but of greater moment was the re-trap of one bird in 1995 (5 August) in the same island as caught in the previous year (28 July) (Brace et al. 1996). Since K. hudsoni withdraws entirely from Bolivia during the austral summer to breed in central Argentina (Canevari et al. 1991), this particular individual is likely to have undertaken a round-trip of no less than $4000 \mathrm{~km}$. In surveying the Chimane ecosystem programme area, Parker (1989) (with colleagues) reported seeing the species daily (up to 12 birds) in habitats similar to those indicated above. 
Cock-tailed Tyrant Alecturus tricolor (NT) This species, which was listed by Miranda et al. (1991), is known within Bolivia only from scattered localities in Beni, Santa Cruz and La Paz (Ridgely and Tudor 1994). When surveying the Yacuma area (Beni) c. $150 \mathrm{~km}$ north of the B.B.S. in 1976 (November and December), Remsen (1986) located the species in grassland (one or two sightings per day). Closer to the B.B.S., Parker and colleagues (Parker 1989, Parker et al. 1991) found it in small numbers (up to 10 per day) between 15 and $45 \mathrm{~km}$ to the west (in June) but commented that much seemingly suitable habitat (tall grass) scrutinized, yielded no records. Such localized occupation by this declining species within large swathes of seasonally inundated savanna merits investigation (see Discussion).

Unicoloured Thrush Turdus haplochrous (NT) This lowland Bolivian endemic was, prior to being located in the reserve in 1992 (White el. al. 1993, 1995), known solely from six specimens relating to three localities in Beni (see Collar et al. 1992), and from one sight record by T. A. Parker in Santa Cruz (J. Bates in litt. 1994). It has been found since in the Isiboro Sécure National Park in the south of Beni, with two specimens being collected in November 1993 (M. Carreño verbally 1995, Wege and Long 1995); we have verified the identification of the specimens concerned, which are deposited in the Museo de Historia Natural "Noel Kempff Mercado" (Santa Cruz). Observations at the B.B.S. were made in flooded riverine forest (várzea) in the vicinity of FNC; one individual was seen and one trapped on 7 September. Further sightings were obtained on 10 and 16 September involving one and two birds respectively. It seems likely that future surveys in similar terrain will uncover additional localities and recognition of this has come already with its demotion from threatened to nearthreatened status (Collar et al. 1994).

White-rumped Tanager Cypsnagra hirundinacea (NT) This tanager of cerrados, campos and savannas is, as might be expected, confined to Beni and Santa Cruz within Bolivia (e.g. Parker 1989, Parker and Rocha 1991, Davis 1993, PearceHiggins 1996). It was added to the B.B.S. inventory by S. L. Hilty (unpubl. data) in 1988 but has not been recorded subsequently; thus it is seemingly only a wanderer to this area.

Black-masked Finch Coryphaspiza melanotis (THR - vulnerable) First reported in the reserve in 1995 when, over the period 9-28 August, a small number (34 pairs) were seen in an area of savanna largely devoid of bushes or trees, 2 km north of El Porvenir (R.C.B., J.H., J.W.P.-H.); a male and female were trapped (together) on 26 August. It would appear to be locally common in Benian grasslands, and has been seen within $15+\mathrm{km}$ (to the west) of the reserve previously (Remsen 1986, Parker 1989). Reported from La Paz but curiously not from Santa Cruz as yet (Arribas et al. 1995).

Dark-throated Seedeater Sporophila ruficollis (NT) Two males were trapped in scrub in the PVR éstancia on 17 and 22 August 1994. In 1995 several were seen (including males on 6 and 30 August) in the TRF éstancia, and a total of 14 small Sporophila trapped (8-13 August), of which eight were readily identifiable 
ruficollis males (R.C.B., J.H., J.W.P.-H.)). The species was claimed by White et al. (1993) but since only non-breeding individuals (20) were involved we are not prepared to accept that sighting. Within Bolivia it is known from Beni, Santa Cruz, La Paz and Tarija (Arribas et al. 1995). On the savanna at Los Fierros within the Noel Kempff Mercado National Park (Santa Cruz), S. ruficollis outnumbers $S$. hypoxantha by two to one and $S$. hypochroma by over three to one (Pearce-Higgins 1996, Pearce-Higgins et al. unpubl. data), relative abundances which reflect the situation to date at the B.B.S. It should be noted that both local migration and nomadic movements may result in considerable seasonal variation in the abundance of the species (S. Davis in litt. 1996).

Grey-and-chestnut (Rufous-rumped) Seedeater Sporophila hypochroma (NT) First noted at the B.B.S. by S. L. Hilty (unpubl. data), it is found uncommonly in savanna-dominated areas (Miranda et al. 1991). White et al. (1993) commented that they had only one definite sighting (20 August 1992), a male accompanying a flock of Double-collared Seedeaters S. caerulescens. On both 19 and 30 August 1995 a small group (c. five) of small Sporophila was seen alongside the San Borja to San Ignacio road, which fortunately included, on each occasion two male $S$. hypochroma in breeding attire (R.C.B., J.W.P.-H.).

\section{Discussion}

\section{Awian diversity}

Documentation of the avifauna of the B.B.S. has proceeded apace since the inception of the reserve in 1986, but until now a comprehensive and annotated treatment of this fauna has been lacking. Our paper, which lists over 70 species not mentioned in Miranda et al. (1991), has filled this gap. Of the species additions listed here, 52 can be attributed to the endeavours of White et al. (1993) in 1992, and 21 are a result of our survey work undertaken since. In addition to the four threatened species mentioned specifically in the Introduction, no less than 15 near-threatened birds (Collar et al. 1992) are listed now. Significantly, amongst these 19 species are 11 that rely wholly or partially upon the savanna habitat (see below).

\section{Species richness in different habitats}

We have attempted in Appendix 1 to detail the range of habitats occupied by the various species. Because our fieldwork has been restricted to certain locations within the reserve, we have had to rely heavily upon distributional information tabulated in Miranda et al. (1991). In doing so it has become apparent that although that data source is rich, it is not without flaws linked to the obvious misidentification of some species across certain, but not all, habitats. Consequently, we have deemed it appropriate to edit that information where necessary. We think that the habitat classification scheme adopted here, which was simplified from that used by Miranda et al. (1991), provides an effective working framework, although we do appreciate that certain categories are ecolo- 
gically very close, especially so during the austral summer when much of the savanna and forest is inundated.

Notwithstanding the obvious dangers in both categorizing habitat diversity and assigning avian occurrence to those categories, such an approach does yield rough measures of species richness in different environments. However, strict comparisons in this regard should not be attempted since some habitats may have received less attention than others. Inspection of the column totals in Appendix 1 reveals that with the exception of the cyperacean swamps (CS) and Río Manique (RM) categories, all habitats contain 100 or more species. Although all the forest categories have high scores, that for riverine forest stands apart. Its apparent richness is due presumably to the fact that it is comprised of several subhabitats, though relative ease of observation at river margins may be an influential factor also. There is considerable species-sharing of landbirds across riverine, seasonally inundated (várzea) and terra firme forest types (e.g. Accipitridae, Columbidae, Psittacidae, Picidae, Dendrocolaptidae, Thamnophilidae). Amongst examples given by Remsen and Parker (1983) of habitat expansion of typical river-associated species into terra firme, Blue-throated Piping-guan Pipile cumanensis, Collared Trogon Trogon collaris, Blue-crowned Trogon T. curtici, Amazonian Antpitta Hylopezus berlepschi and Russet-backed Oropendola Psarocolius angustifrons all show the same tendency at the B.B.S. The apparently less distinctive nature of the avifauna of riverine habitats at the reserve is likely to be a consequence of the fact that much of the reserve is a closely knit mosaic of forest types (including swamp forest), with a proportion of the forest transitional in nature.

Turning to the forest islands, their apparent richness is perhaps a little surprising given that the normal expectation is to find relatively depauperate faunas in such relatively isolated situations (MacArthur and Wilson 1967, Bierregaard et al. 1992). This is not considered in detail here but pertinent factors are (i) that the diversities of these islands are swelled by species which use adjacent "curichis" (also fairly species-rich) and savanna, with the margins of the former providing ostensibly suitable access corridors; and (ii) that because the islands have had a long history (see Introduction) and are not a recent product of forest clearance, an avifaunal composition quite distinct from that of forests fragments has had time to become established. Examples of species found commonly in islands but rarely in the Florida fragment include, for example, Speckled Chachalaca Ortalis guttata, Blue-and-yellow Macaw Ara araruana, Rusty-backed Antwren Formicivora rufa, Myiarchus spp. and Plush-crested Jay Cyanocorax chrysops. Thus the "picture" which emerges for the more open areas of the reserve is not dissimilar to that of the mosaic of rainforest types referred to already; the several constituent habitats there blend physically and biotically, although of course the savanna per se, and chaco-like areas also, are used by substantially lower numbers of species (125 and 123, respectively). Indeed, if one considers strictly savanna-based (non-raptorial) species that are both widespread and abundant, only two qualify: Grassland Sparrow Ammodramus humeralis and Wedge-tailed Grass-Finch Emberizoides herbicola.

\section{Biogeographical representation}

Table 1 provides a breakdown of the numbers of species associated with general biogeographical/vegetational regions in South America; note that 102 species 





have been scored for two or more regions. Overall, almost half of the scores are for Amazonian distributions, with about half of those in turn relating to species having extensive ranges within Amazonia. Not surprisingly, the east Amazonian grouping scores only $7 \%$ but surprisingly the west Amazonian together with the Andean foothill distributions account for just $16 \%$ (the passerine score being almost exactly twice that of non-passerines). Cerrado and chaco scores taken together comprise $23 \%$ of the distributions. Because it is not easy to split cleanly these two groups, a compromise solution has been adopted, with cerrado and chaco-cerrado categories being used. Despite this, the total cerrado representation (and count) is, as anticipated, more than double that of chaco-cerrado. Virtually all remaining scores (total of $32 \%$ ) relate to species with extensive lowland distributions, with non-passerines having, not unexpectedly, a disproportionate showing. Note that input from the Bolivian Yungas only $150 \mathrm{~km}$ away is relatively limited.

\section{Threatened and near-threatened birds of the savanna}

Three of the four threatened species listed for the B.B.S. occur in the savanna, with two being restricted to this habitat; of the 15 near-threatened birds, the savanna plays host to no less than eight, of which five are confined to it (Table 2). A further species, Hudson's Black-Tyrant frequents the forest islands set within the main (El Porvenir) savanna block; it is an austral migrant, which may be in residence throughout the winter and can remain faithful to a particular island for more than one winter (Brace et al. 1996).

Tropical grasslands south of the Amazon in Brazil, in eastern Bolivia and elsewhere have been, or are being, converted rapidly for cattle production or agricultural purposes. The combined impact of heavy grazing, annual burning, introduction of non-native grasses, hunting (e.g. Greater Rhea) and trapping (e.g. Sporophila spp.), have influenced a substantial proportion (perhaps as great as $90 \%$ ) of original habitat. Consequently many species typical of open and semi-open areas have suffered greatly (Bucher and Nores 1988, Cavalcanti 1988, Collar and Andrew 1988, Willis and Oniki 1988, Collar et al. 1992), such as the threatened Black-masked Finch Coryphaspiza melanotis, which has become very local throughout its extensive range (Ridgely and Tudor 1989) and which could not be found recently in formerly occupied sites in north-east Argentina (Pearman and Abadie unpubl. data). Our sightings, together with those of Remsen (1986), Parker (1989) and Parker et al. (1991), indicate that this finch and the near-threatened Sharp-tailed Tyrant, Cock-tailed Tyrant, White-rumped Tanager, Dark-throated Seedeater and Grey-and-chestnut (Rufous-rumped) Seedeater, are widespead, albeit patchily so, in the lowlands of Beni. Therefore it is clear that this department of Bolivia consitutes an important refuge for them. This region may be important also for the Long-winged Harrier Circus buffoni, which is local over much of its extensive geographical distribution and likely to be affected by wetland degradation (Bierregaard 1994).

The precise influence of burning on the ecology of the savanna, principally during the August to September period, is unclear but there is no doubt about its scale, which can be appreciated readily by flying into the department capital, Trinidad, during these months. For example, during August 1995, the airport 


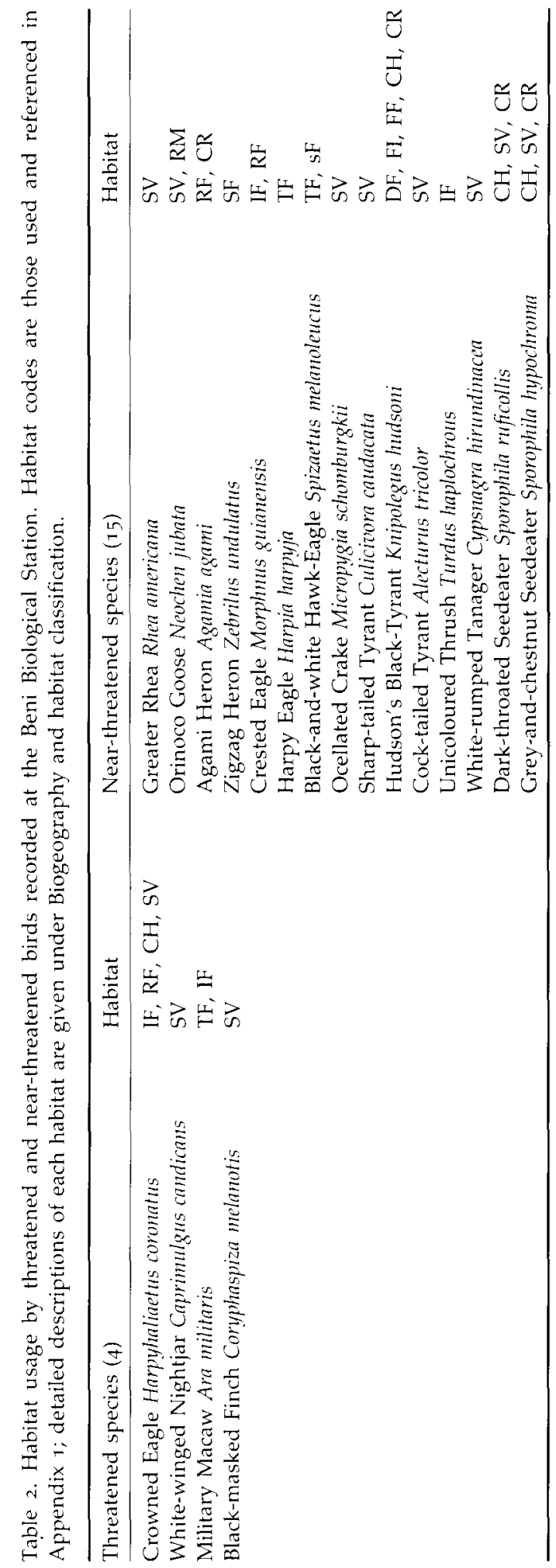


at Trinidad was closed for several days because of poor visibility due to smoke haze (T. Pérez verbally 1995), and the peripheries of several of the forest islands which we were investigating in the El Porvenir éstancia at the B.B.S. were invaded by fires started in adjacent properties. Although some grassland species can tolerate regular burning and some, e.g. granivorous birds such as Sporophila spp. and Blue-black Grassquit Volatinia jacarina (Davis 1993) may actually benefit from it, for others such disturbance results in their disappearance, e.g. Ocellated Crake and Cock-tailed Tyrant (Cavalcanti 1988). Negret and Teixeira (1984) report that in avoiding fires, Ocellated Crakes "appeared dizzy and intoxicated" and were often preyed on by Aplomado Falcons Falco femoralis and could be captured "bare-handed". What should be stressed here is that whilst the irregular occurrence of fires is a quite natural and beneficial hazard of savanna life, the regularity and large-scale nature of induced burning in recent years is, to the contrary, highly detrimental. We have yet to quantify the impact of fire upon the savanna-based forest islands, but have done so with regards to grazing, which results in obvious reductions in the range of birds using island interiors but not in diversities recorded in the peripheries (Brace of al unpubl.).

\section{Conseriation priorities: problems and recommendations}

As a "Man and Biosphere" reserve, the B.B.S. has protected status but this in itself offers no guarantee that threats or social changes prevailing in areas surrounding the reserve will not be without future impact within the confines of the reserve. There are several areas of concern: (i) progressive (legal) encroachment into the northern forested areas by Chimane Indians who live along the banks of the Río Manique; (ii) considerable swelling of the population of San Borja (due principally to a migration of peoples from the Yungas), which is putting pressure on the integrity of the western extremity of the reserve; (iii) the completion (in early 1995) of a bridge over the Rio Manique and associated road upgrading, which has resulted in a marked increase in traffic using the San Borja to Trinidad route passing immediately south of the El Porvenir éstancia, and which is likely to lead to increased settlement along this route; and (iv) logging activities within the Chimane Permanent Production Forest to the south of the aforementioned road, which has led to habitat deterioration and fragmentation, initiated by road construction some 20 years ago. Note that to the north of the Río Manique, the northern boundary of the reserve, the forest gives way similarly to savanna, as it does in part to the east too (see Figure 2). Thus there is a real danger that the main B.B.S. forest block could become isolated totally as a result of these changes, leading to faunal impoverishment.

None of these changes in the near future is likely to put in jeopardy those near-threatened birds found predominantly within this forest block, namely Agami Heron, Zigzag Heron, Crested Eagle, Harpy Eagle, Black-and-white Hawk-Eagle and Unicoloured Thrush, since much of the reserve core is difficult of access. Nevertheless, careful monitoring is required to detect the onset of any putative avifaunal degradation. The park rangers (currently six employed) do receive basic training in biota reportage and continuation of data input from their observations is to be encouraged. Future survey work should aim to include visits to the more remote parts of the reserve (especially areas with cyperacean swamps), where surely additional species for the reserve will be 
discovered. We feel that in the context of forewarning against declines in diversity, it is highly desirable to set up a monitoring programme in both primary and secondary terra firme forest to the south of Totaizal, the village through which wood is transported from logging concessions to the south and whose welfare and prosperity is tied closely to that of El Porvenir.

The 2,500-ha El Porvenir éstancia, which we have shown to support a rich array of threatened and near-threatened species, occupies less than $2 \%$ of the area considered in this paper but it should be emphasized that savanna in the eastern portion of the reserve swells this proportion to approximately $15 \%$. Unfortunately we have not explored the latter area and thus it is not possible at the present time to assess the precise importance of the reserve as a whole to these species. Undoubtedly therefore a future priority is to examine the remaining savanna and assess fully the status of each "core" species. Currently two factors militate against the PVR éstancia acting as an effective conservation zone: (i) the southern third of the savanna is grazed heavily by 100-150 head of cattle, which are damaging many of the forest islands there (see above); and (ii) it is subject to multiple annual incursions of fire. The imminent, though belated, official ratification of PVR as part of the B.B.S. (C. Miranda verbally 1996) should serve to enhance the conservation status of the éstancia, which is treated locally already as an integral part of the Biosphere reserve. It is to be hoped that reserve expansion will take the southern border beyond El Porvenir to at least as far as the Río Matos (see Figure 3), which would help to preserve genetic linkage with good-quality forest beyond. To alleviate damage due to grazing it will be necessary to either curtail severely the presence of cattle (which provide much-needed income of course) or at least to reduce the area over which they graze. Ideally, they should be removed altogether. Unless grazing pressure is alleviated, then a substantial proportion of the forest islands will become damaged irreparably in the near future, due primarily to trampling which impairs sapling growth. Further pressure of this nature is linked to insufficient maintenance of boundary fencing, which permits cattle from neighbouring éstancias to interlope. It is to be hoped that the recent designation of El Porvenir itself as a node of scientific excellence by the Third World Network of Scientific Organizations (M. Hassan in litt. 1994) will result indirectly in money being released to improve the management of this savanna. Additionally, steps must be taken to limit fire damage by, in the first instance, constructing better firebreaks. In the long term, the resolution should be to increase substantially the amount of this habitat within the B.B.S., a proposal which echoes the sentiments of Parker (1989). Due to the local nomadism of many savanna species, protection of adjacent poperties should be sought also.

To end on a more specific note, the status of both Crowned Eagle and Whitewinged Nightjar need assessing urgently. With regard to the latter species, it is intended that a concerted search will made in 1996 when we return to the B.B.S.

\section{Acknowledgements}

We acknowledge support from both Earthwatch and the Department of the Environment, U.K., who sponsored our "Forest Islands of Bolivia" expeditionary research in 1994 and 1995; funding from the latter was in the form of a 
Darwin Initiative grant (to R.C.B.). R.C.B. thanks the former ICBP and the Fauna and Flora Preservation Society for support through the auspices of their 1992 Conservation Awards scheme, which was made possible by financial backing from British Petroleum, to whom he is gratefully indebted.

We thank especially Carmen Miranda of the Academia Nacional de Ciencias de Bolivia, who is Director of the B.B.S., for permission to undertake this work and for continuing encouragement. Many other local people provided logistical support and advice. They are too numerous to be referred to individually but the following should not escape specific mention: Sabina Stab (Resident Scientific Coordinator) and Alfredo Vaca (Estancia Manager) at El Porvenir, Alan and Erika Hesse of the Asociación Armonia (Santa Cruz), Nuria Bernal of the Colección Boliviana de Fauna (La Paz), Susan Davis of the Museo de Historia Natural "Noel Kempff Mercado" (Santa Cruz), and Teresa and Celia Pérez (Trinidad). Contributors to field observations (and our mist-netting activities) included Enzo Aliaga, Antonio Balderraguay, Mark Blazis, Karina Carrillos, Carolina Cáceres, Betty Flores, Marcelo Hinojosa, Omar Martinez, Robin Mitchell, Victoria Rojas, Dennise Quiroga, Gabriel Quisbert, André Rodríguez, Elva Villegas, and a number of the Earthwatch volunteers.

We acknowledge the influence of Adam White, who was instrumental in organizing the 1992 Nottingham University Bolivia Project, which included Giles Duffield, Anthony Payne and Steve Spick; without his pioneering efforts, it is unlikely that this paper would have ever had the opportunity to come to fruition; he was involved in 1994 fieldwork also. We wish to thank Jon Fjeldså and Jan Bolding Kristensen (Centre for Tropical Biodiversity, Zoological Musuem, University of Copenhagen) for providing all the metal rings used during 1994 and 1995 fieldwork. Finally we would like to thank Peter Colston for granting access to collections at the British Musuem (Natural History) at Tring, where skins were examined (particularly of Synallaxis spp.). 


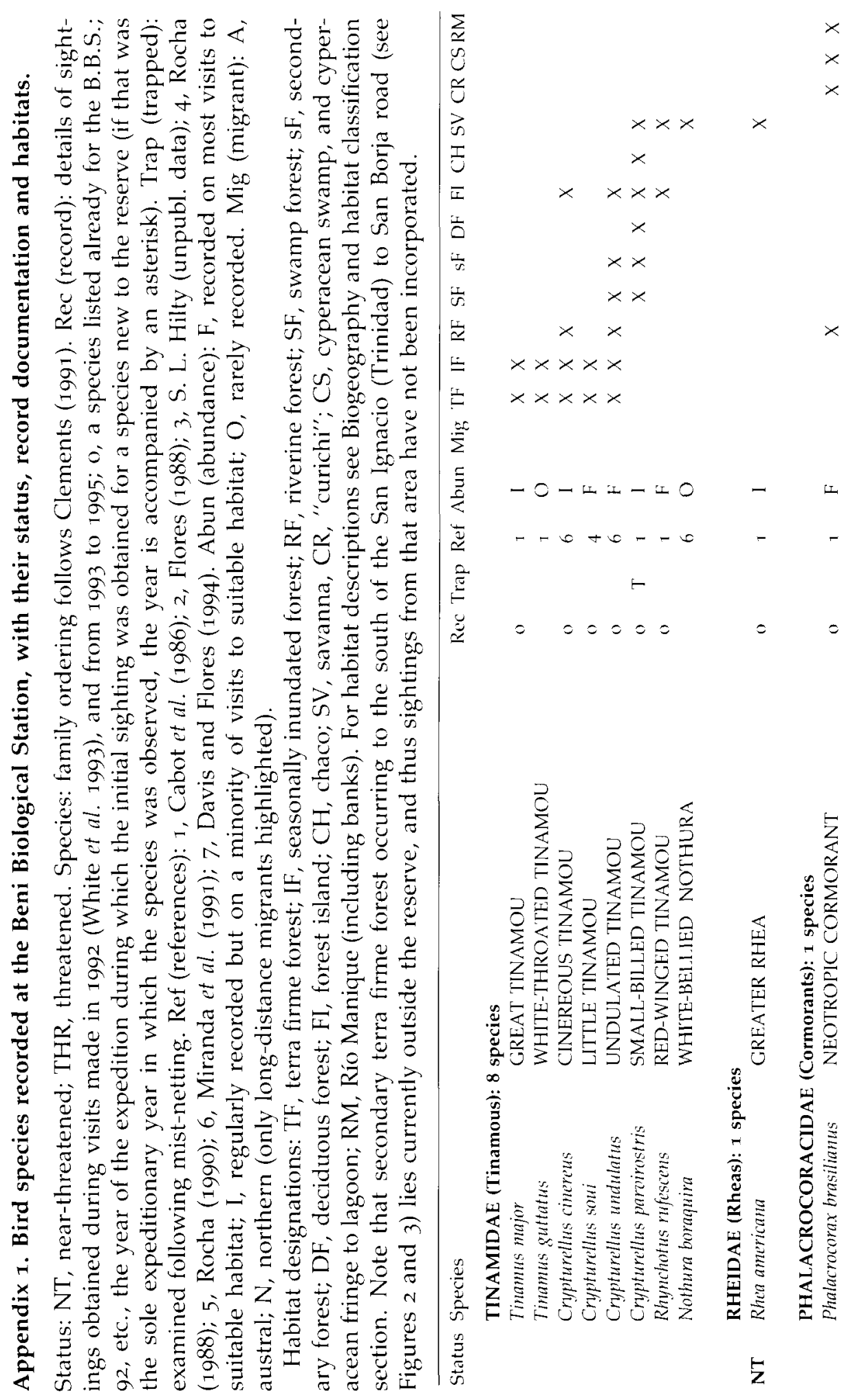




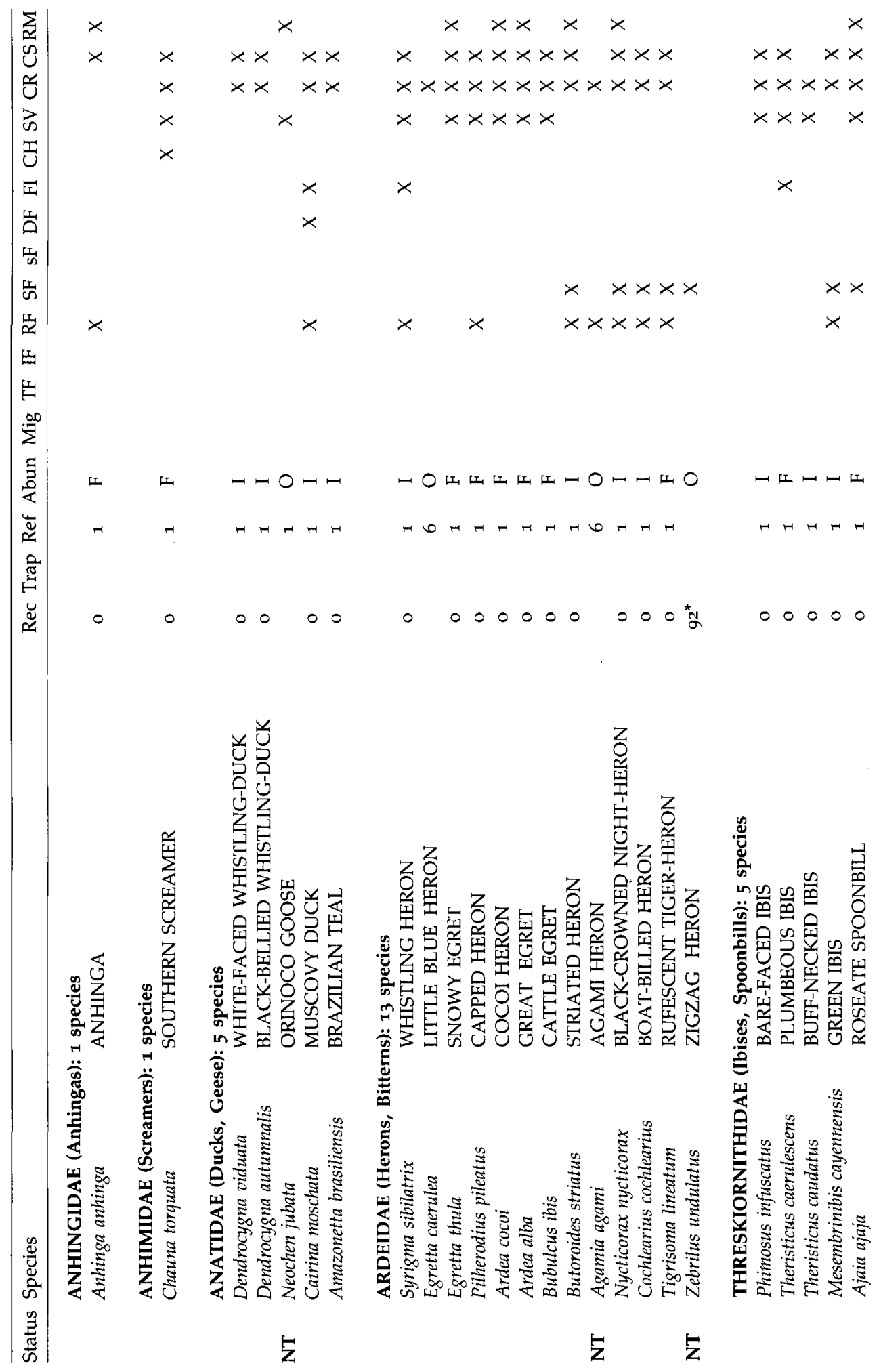



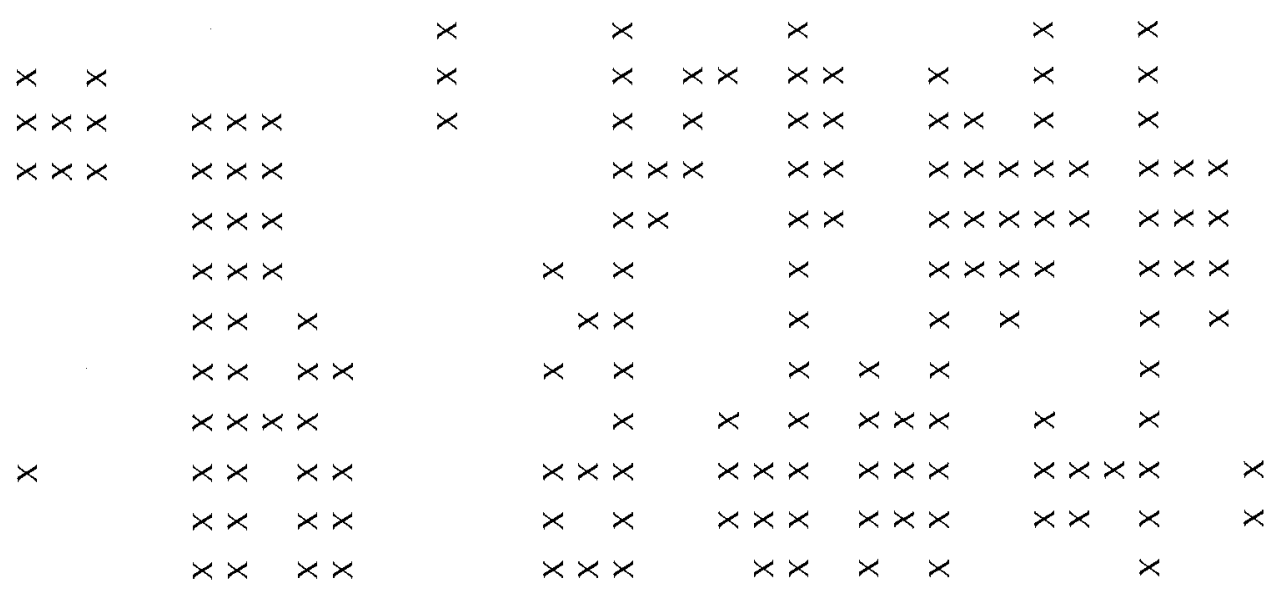

ż

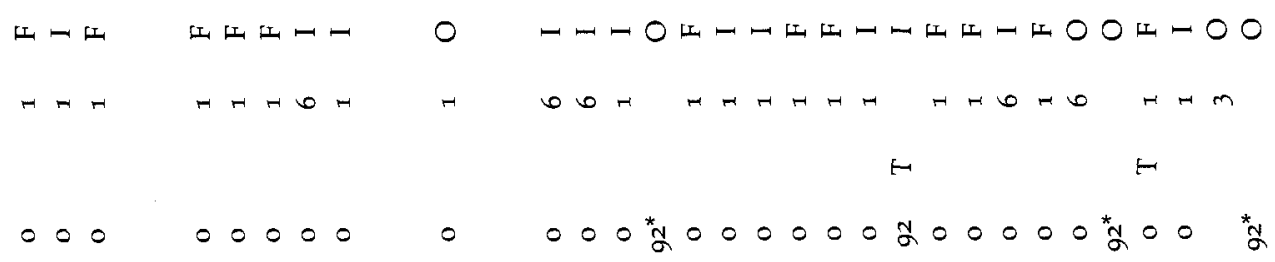

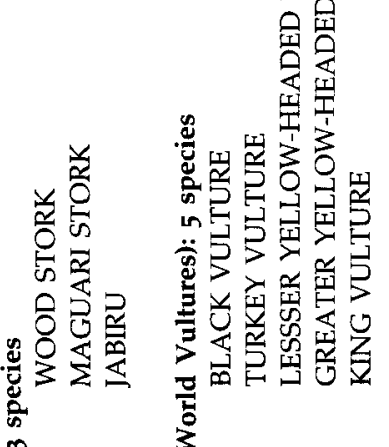

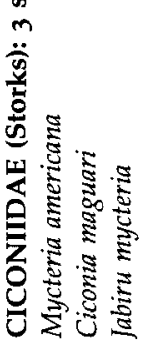

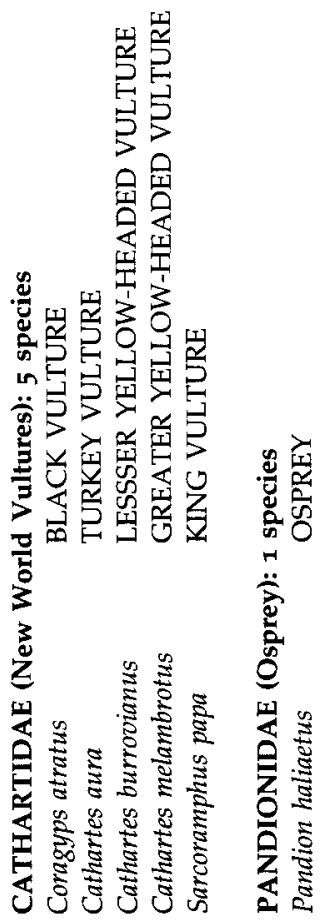

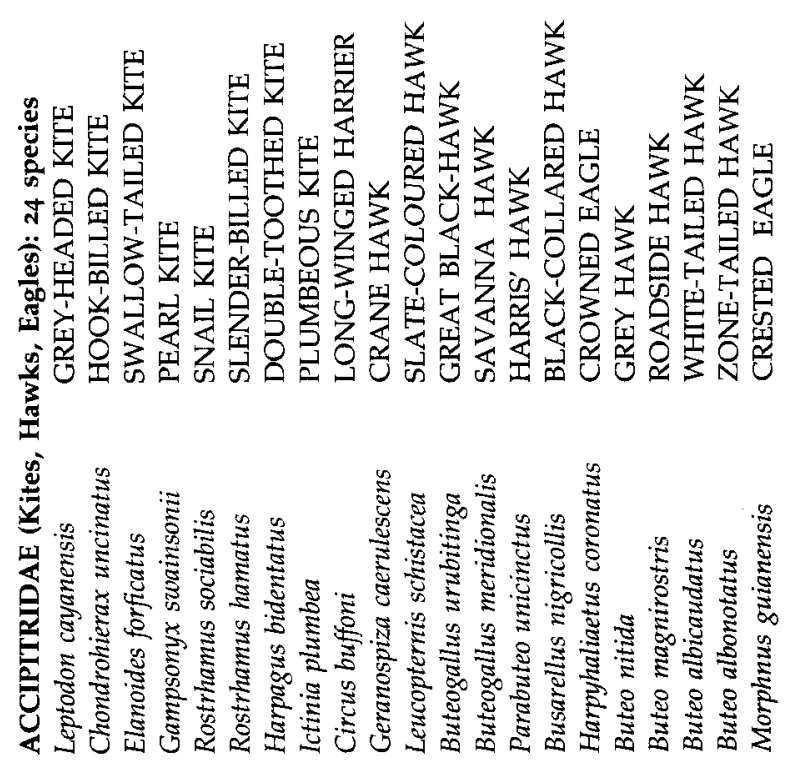

E 


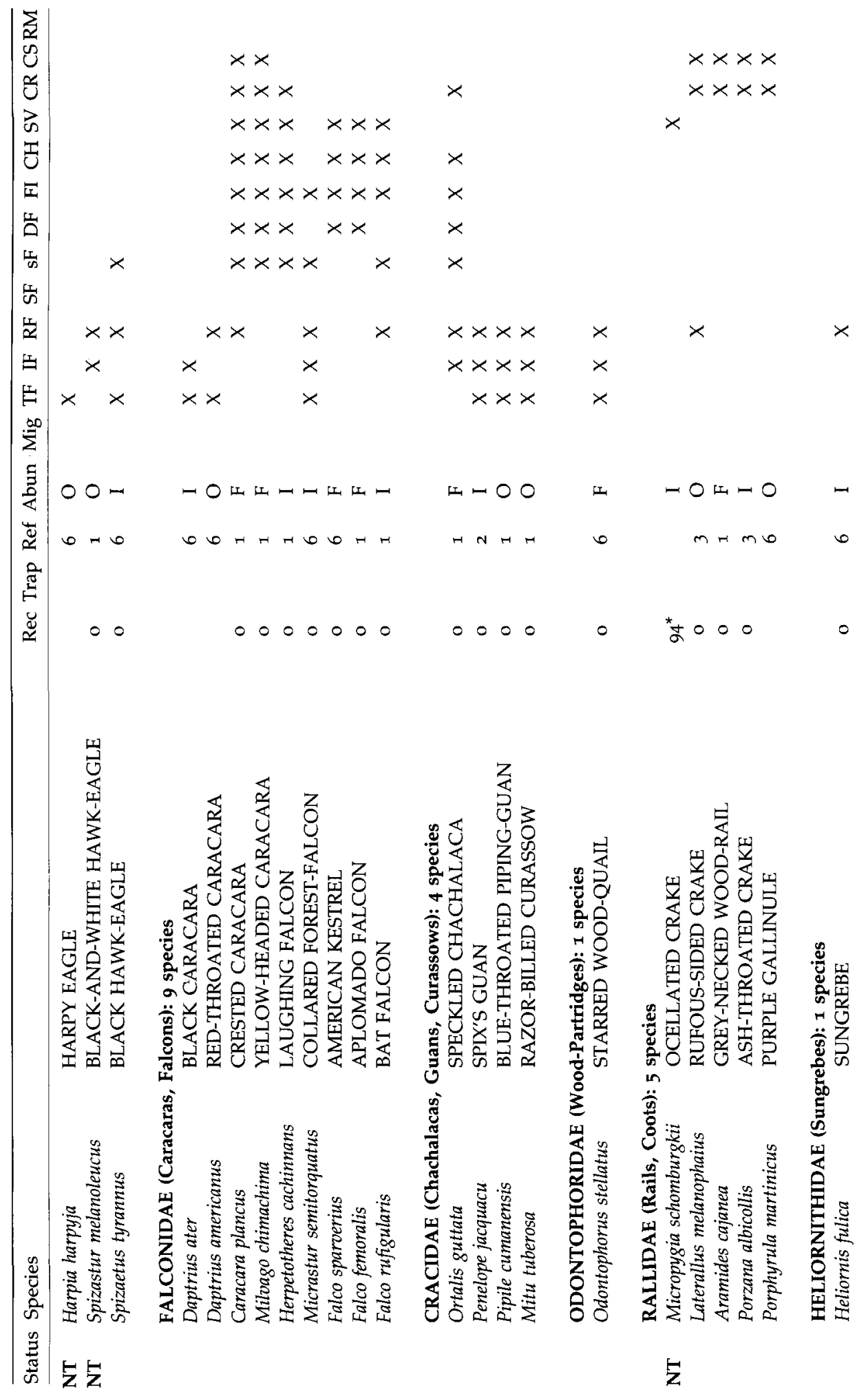



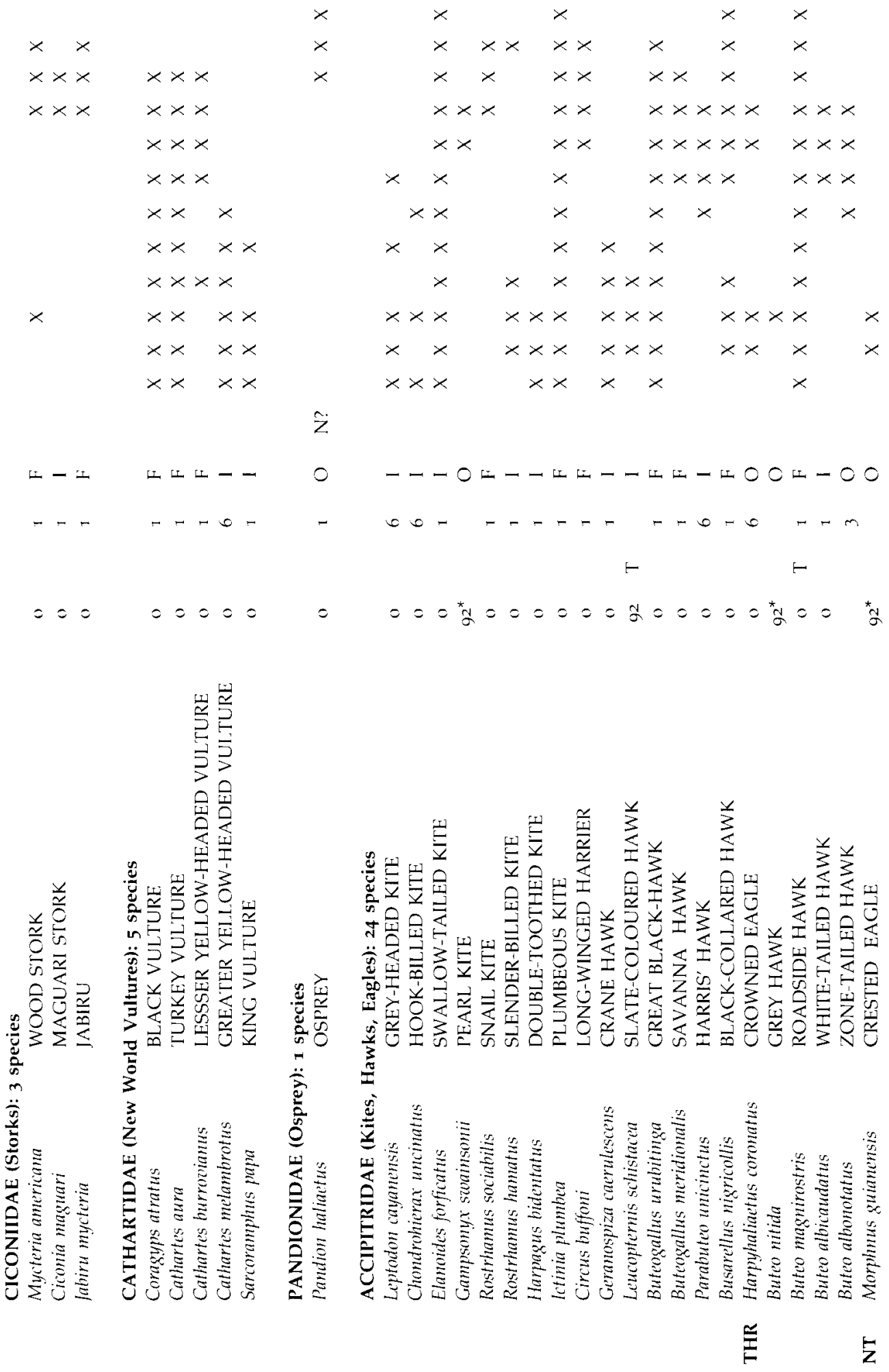


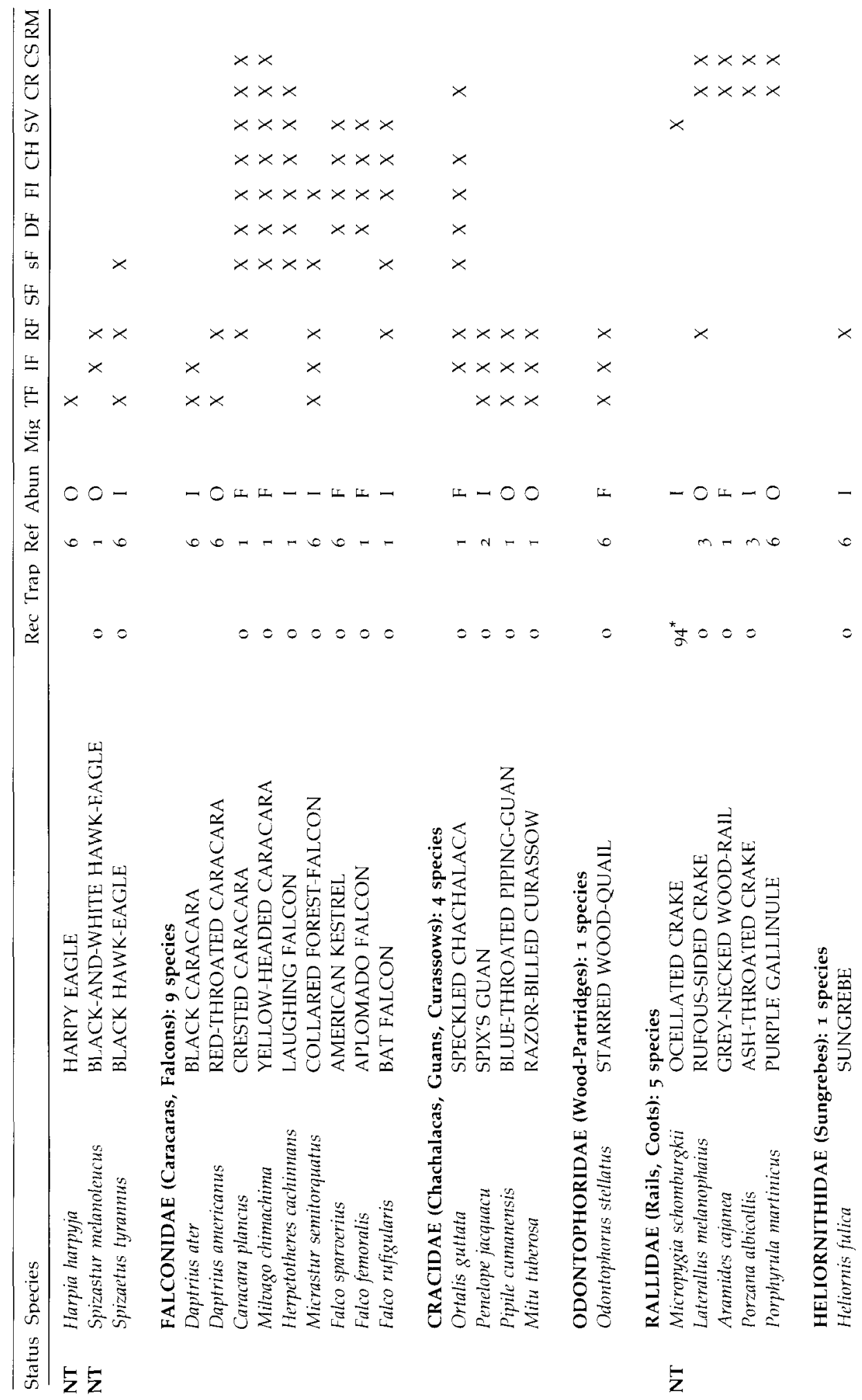



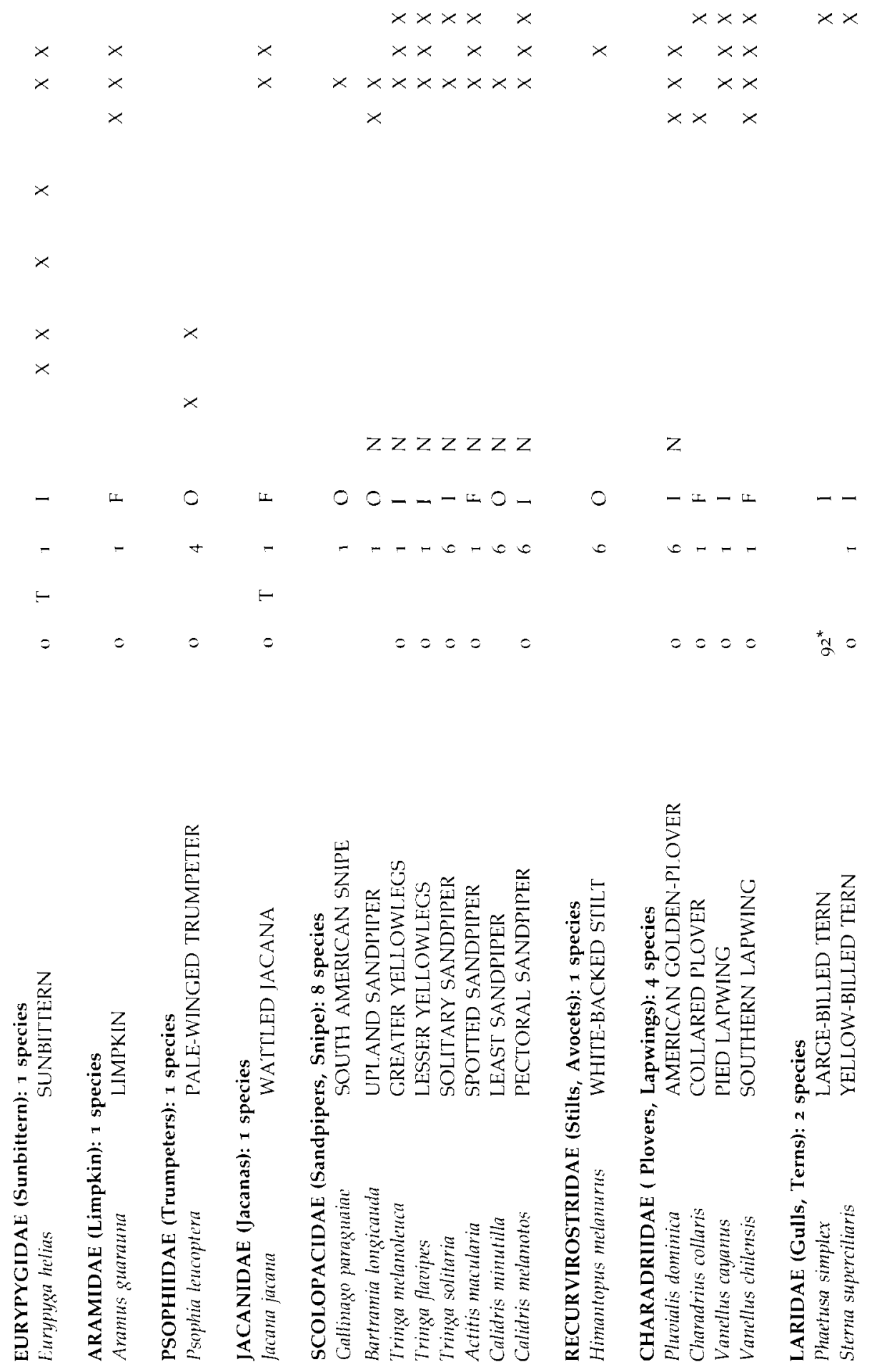


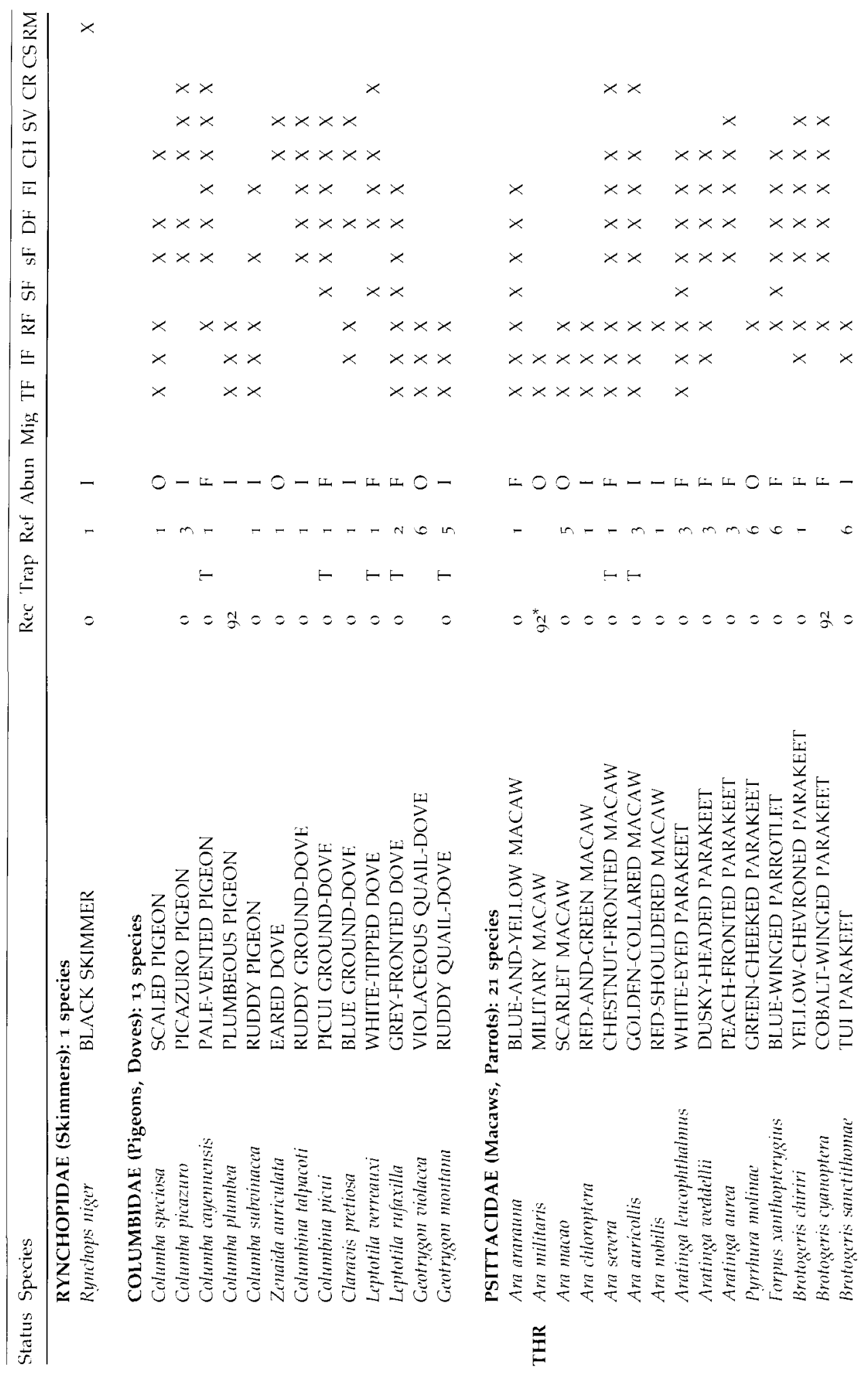



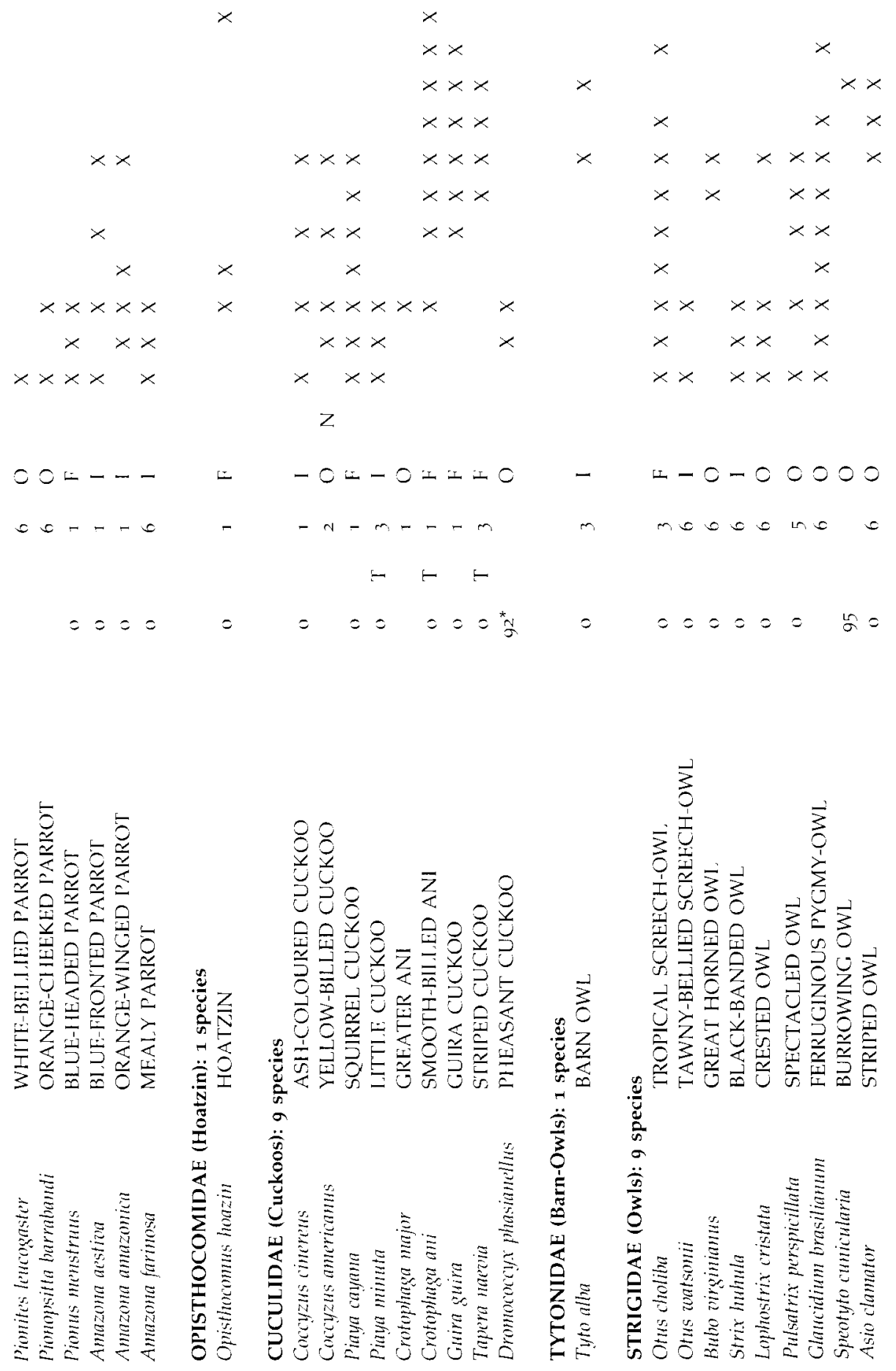


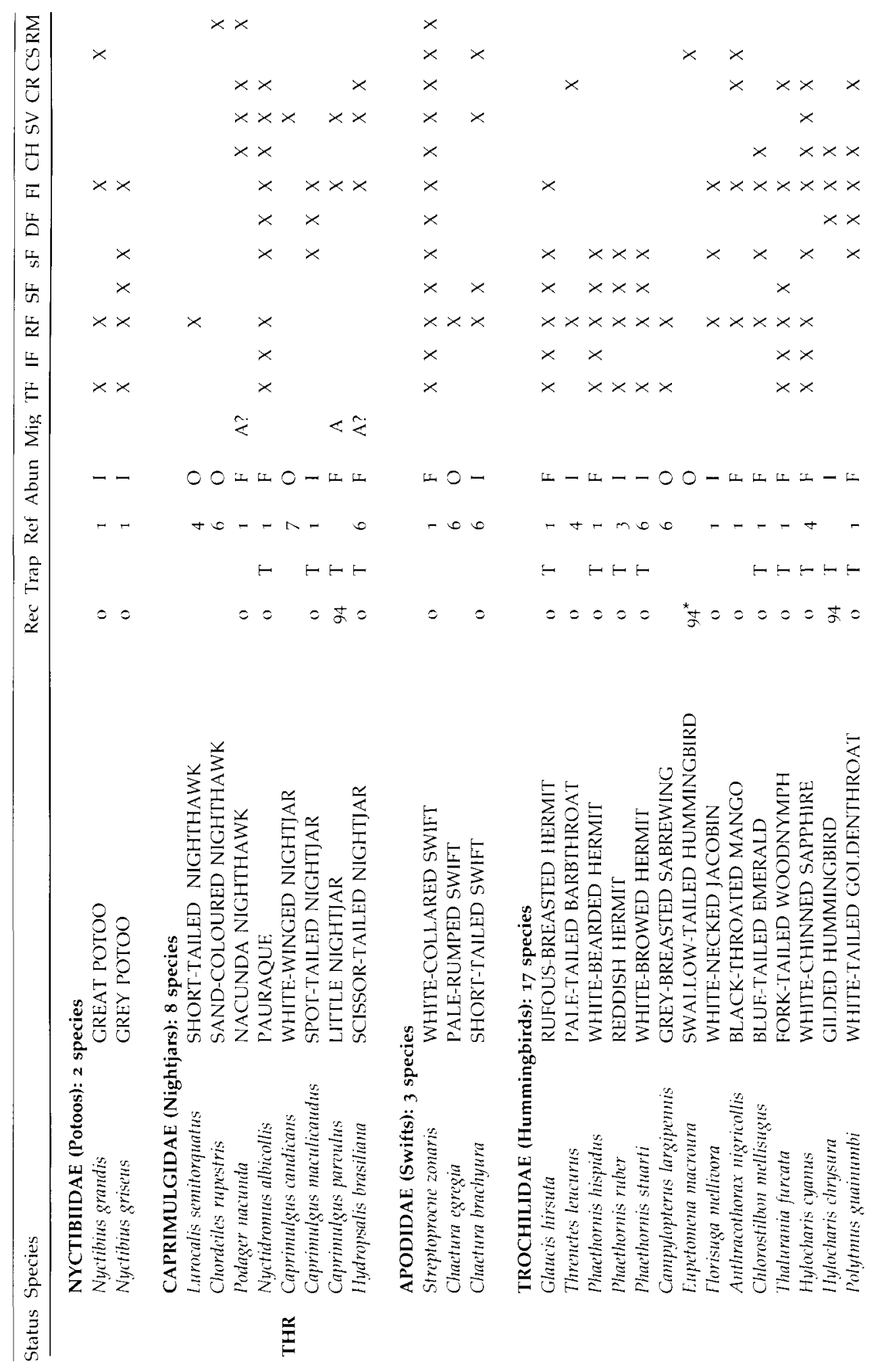



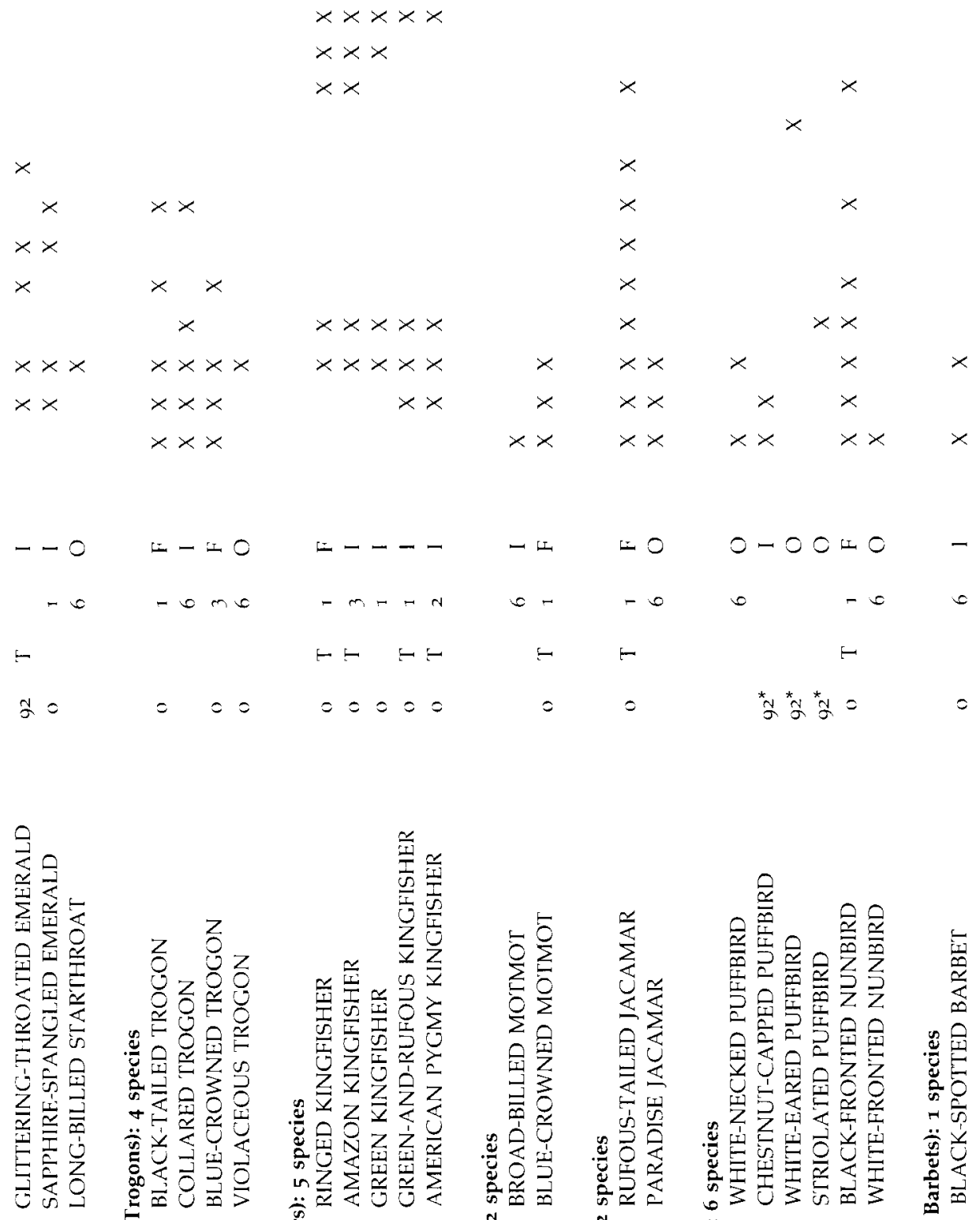

爰说

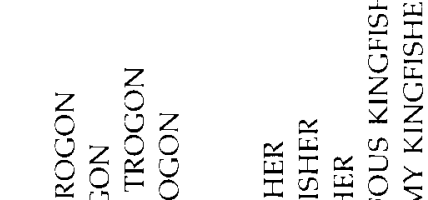

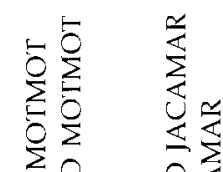



$\frac{5}{4}$

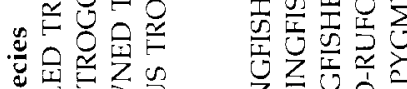



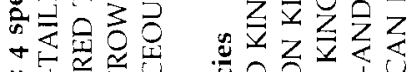

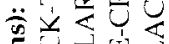

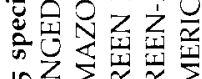

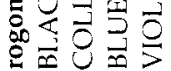

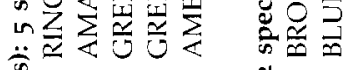

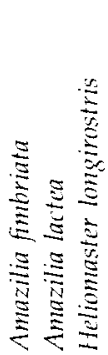

营

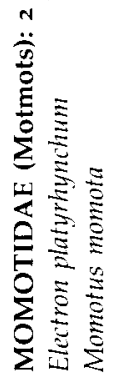

武导

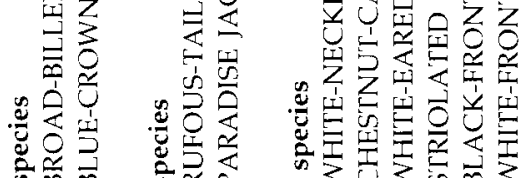

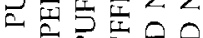

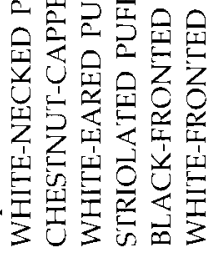

总式

范范
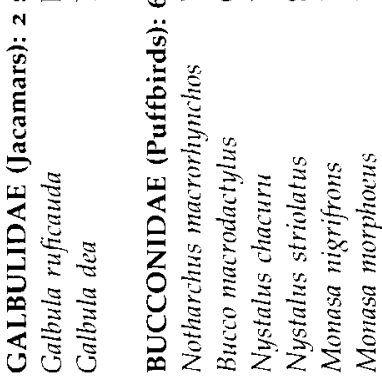

葛 


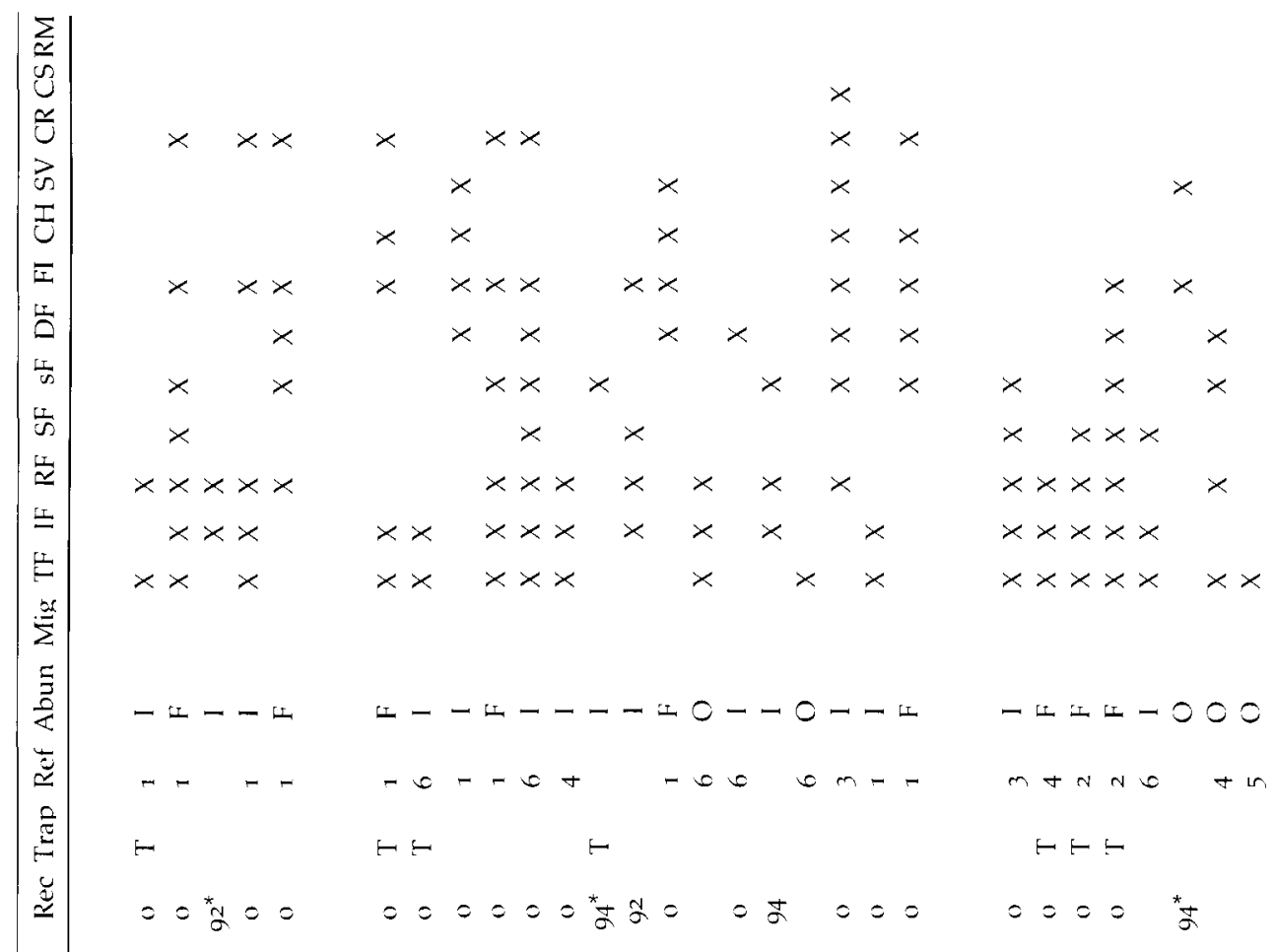




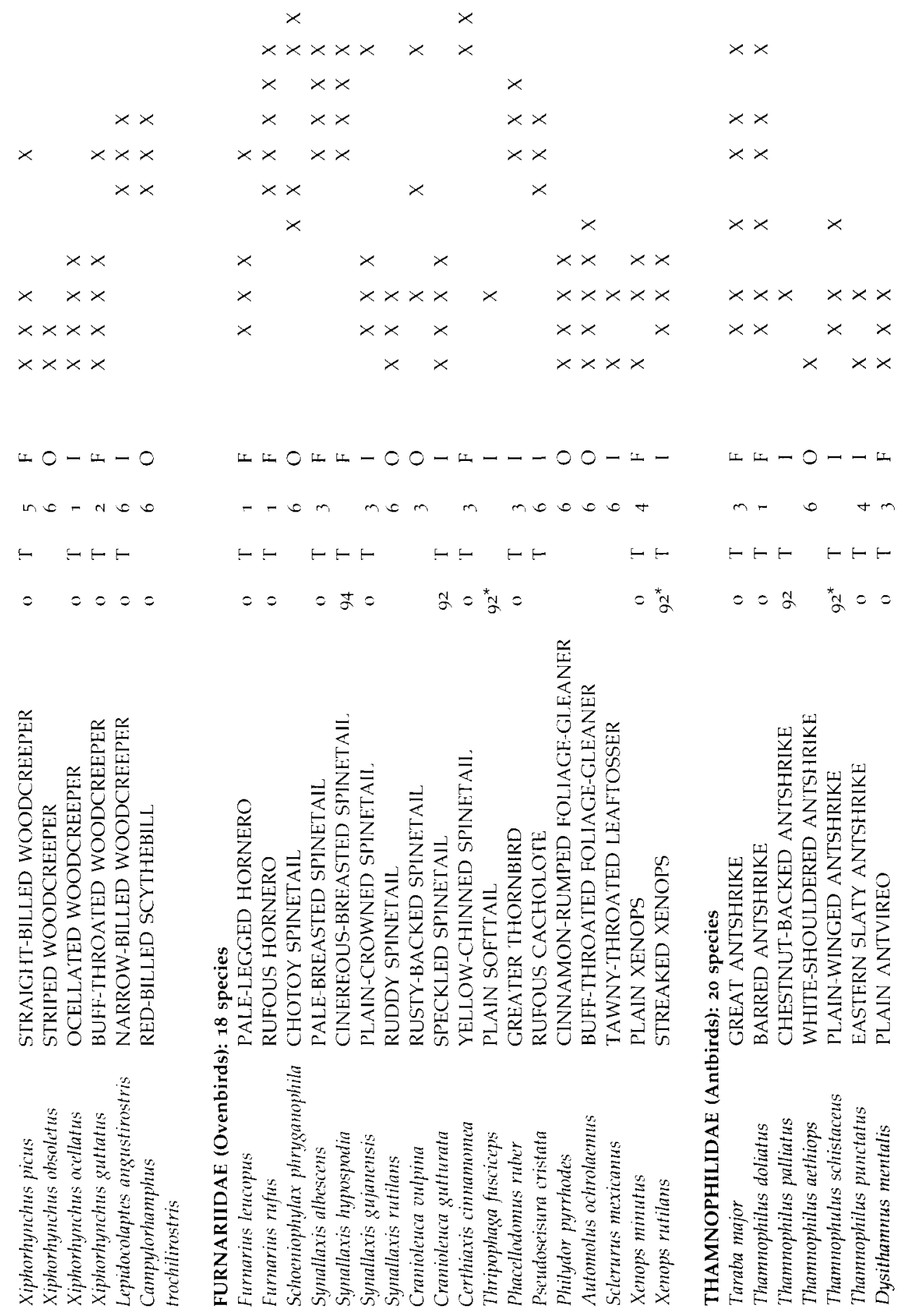




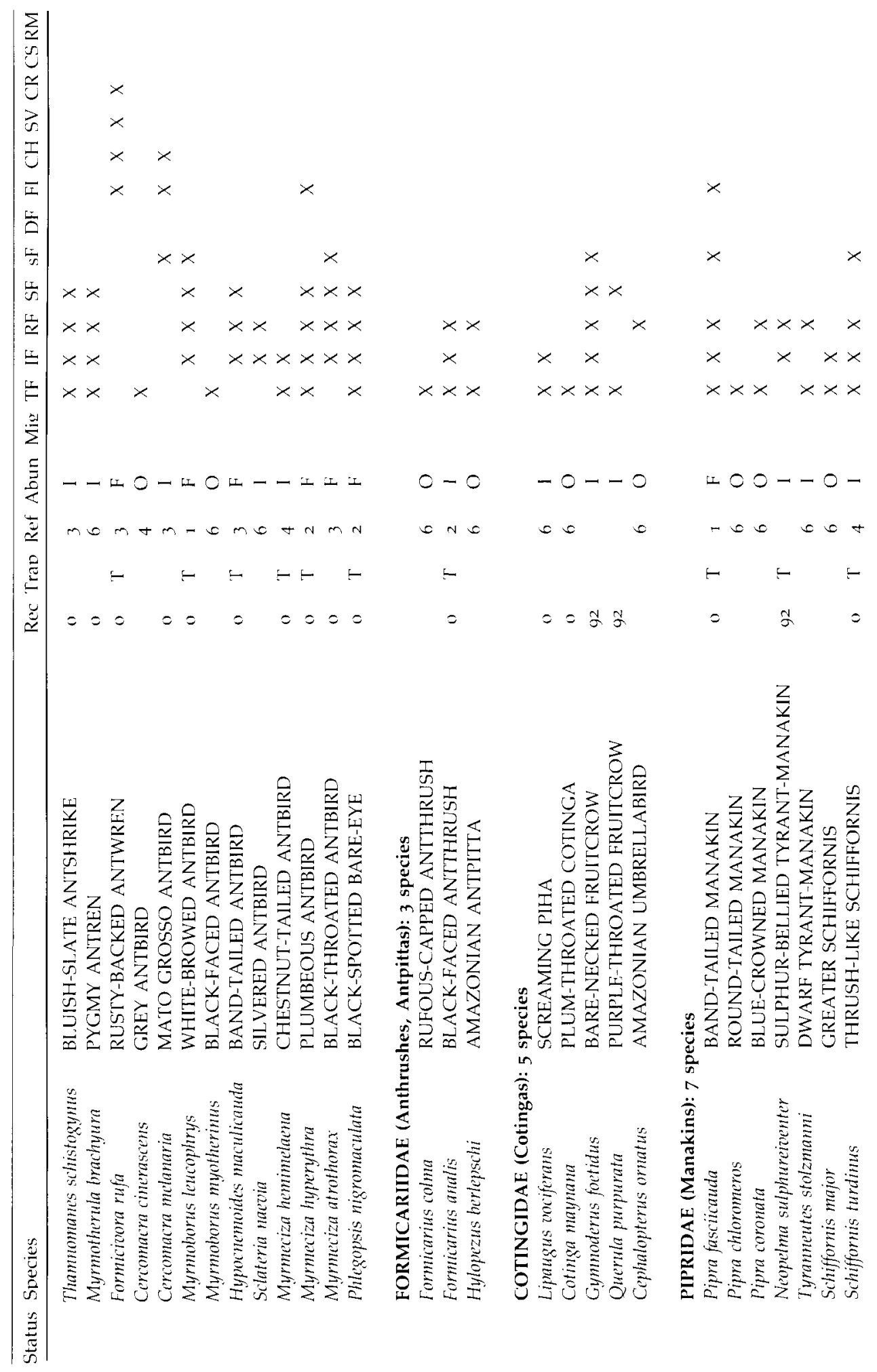




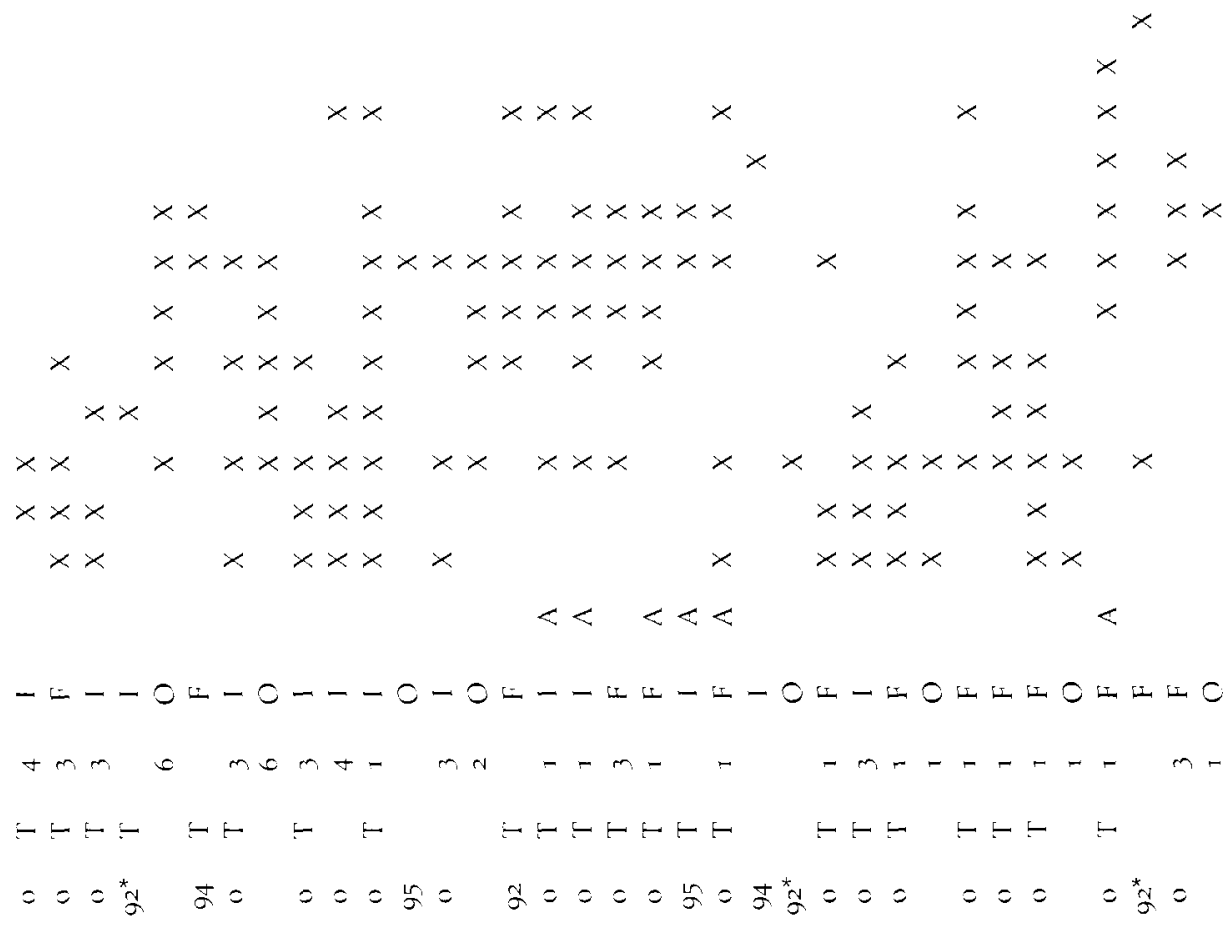

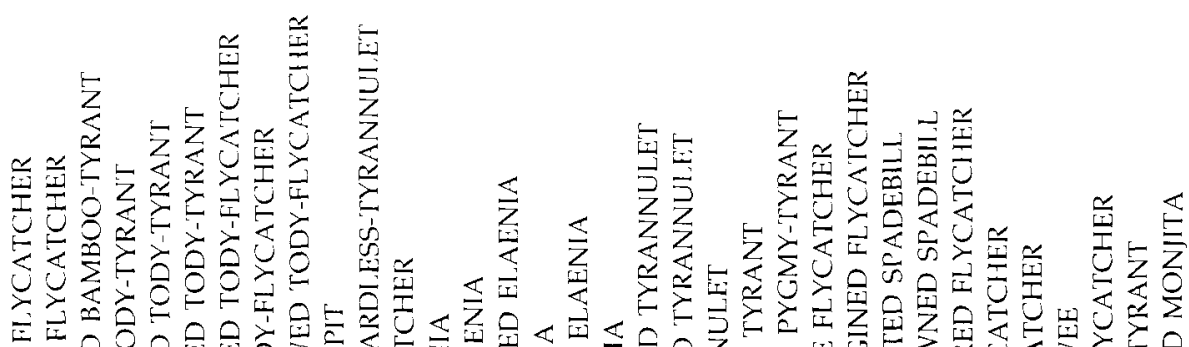

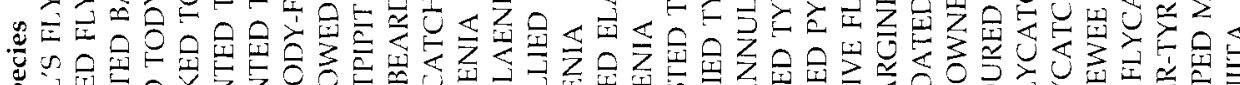

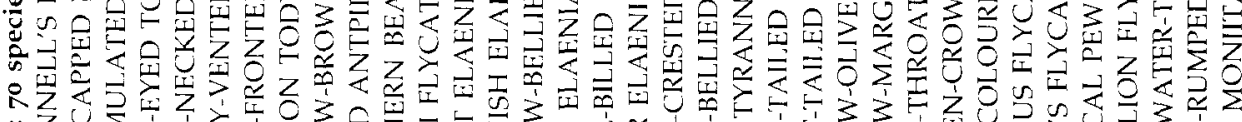

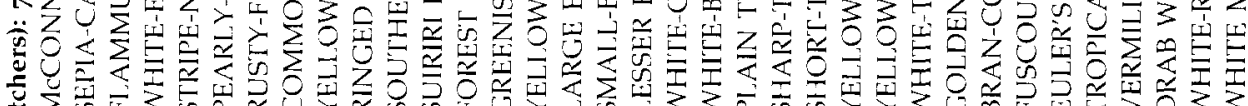

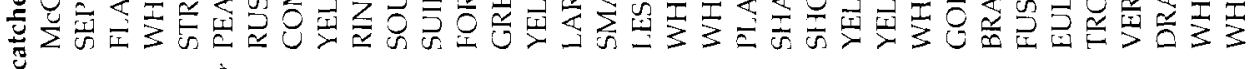
$\frac{\sum^{2}}{2}$

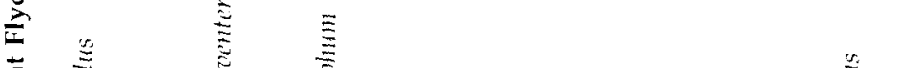

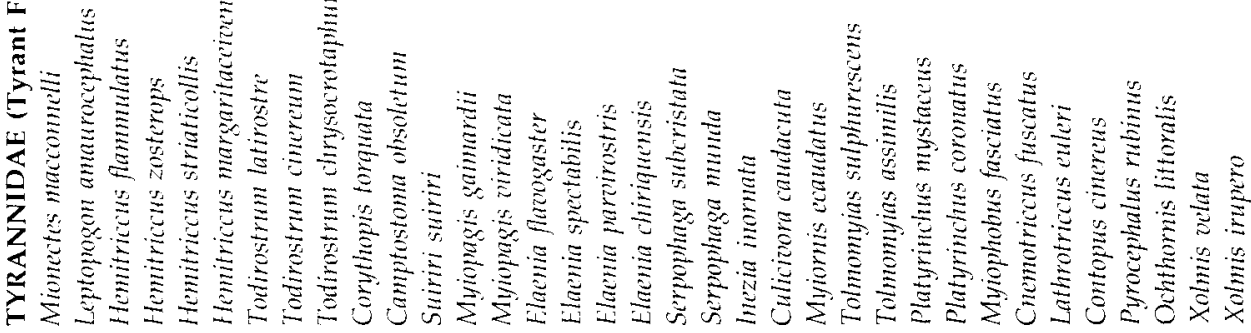




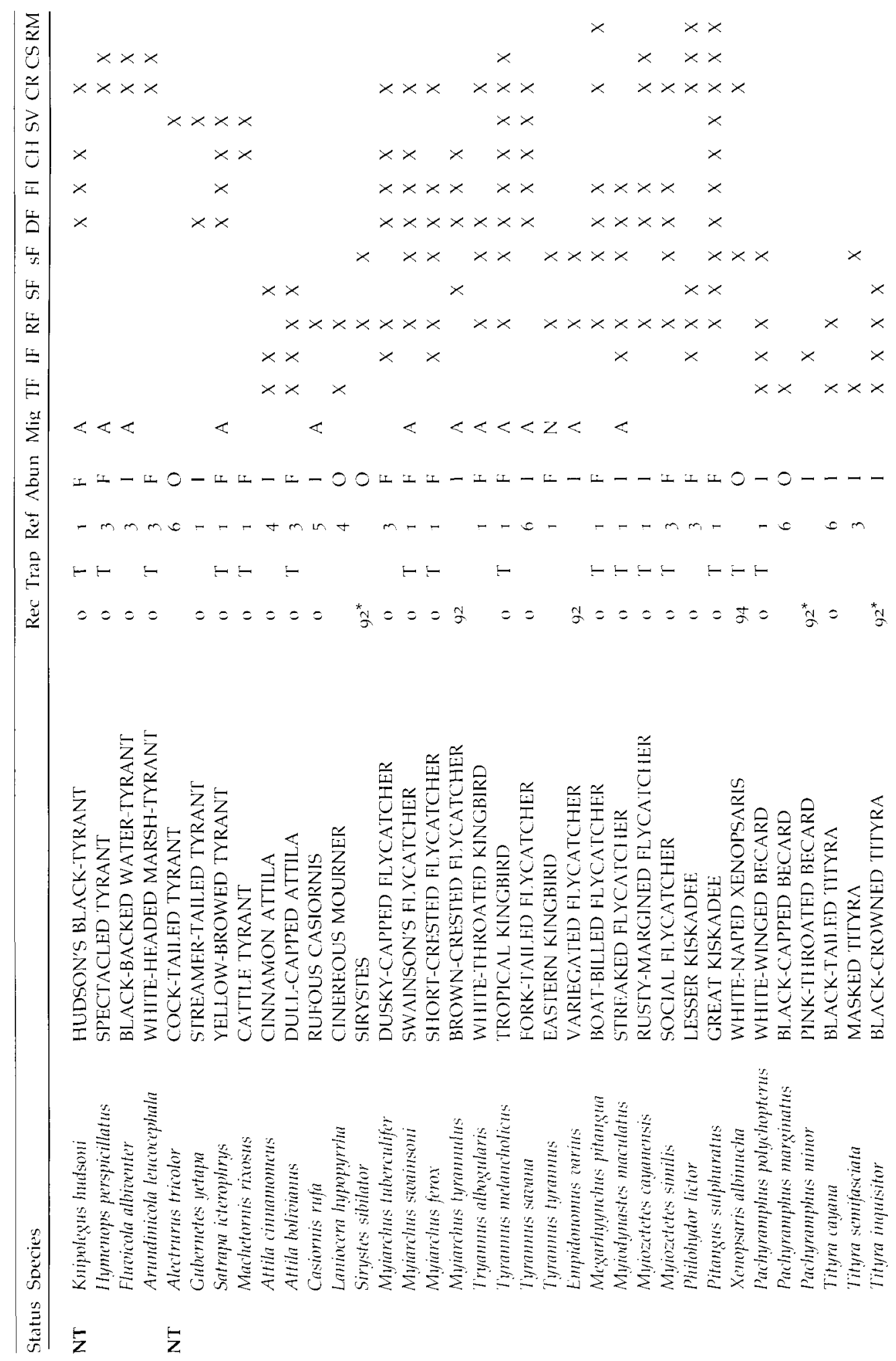



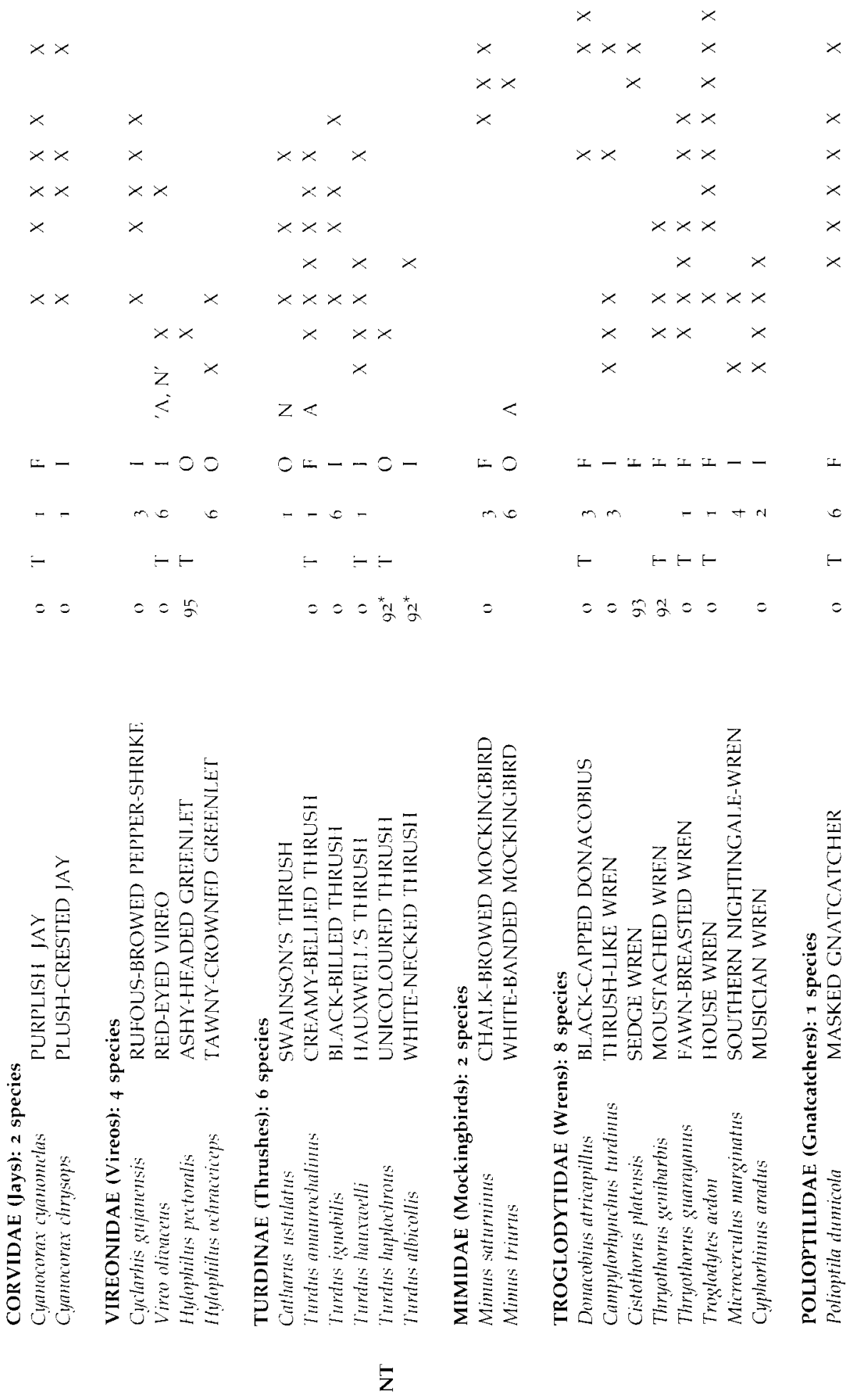


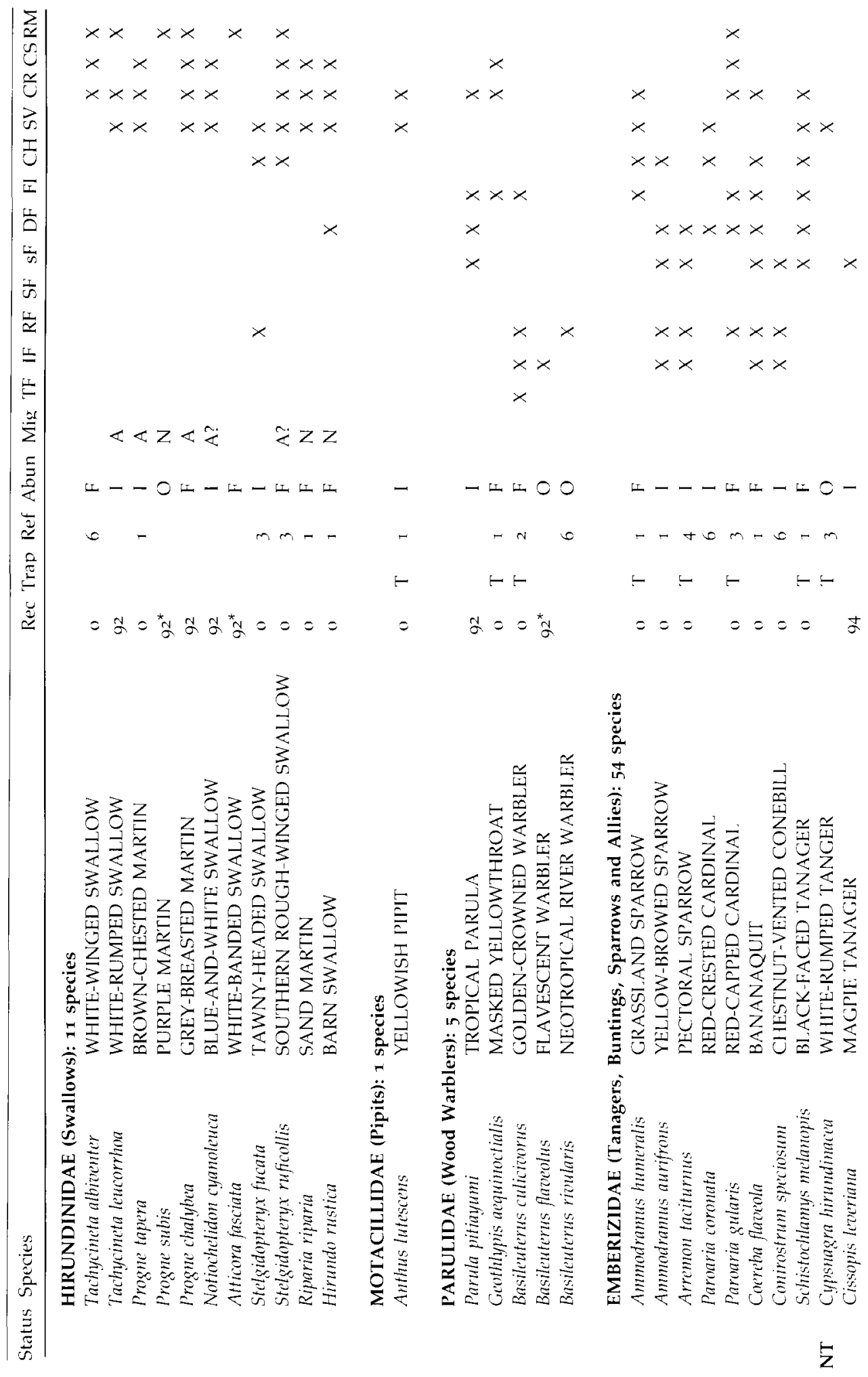




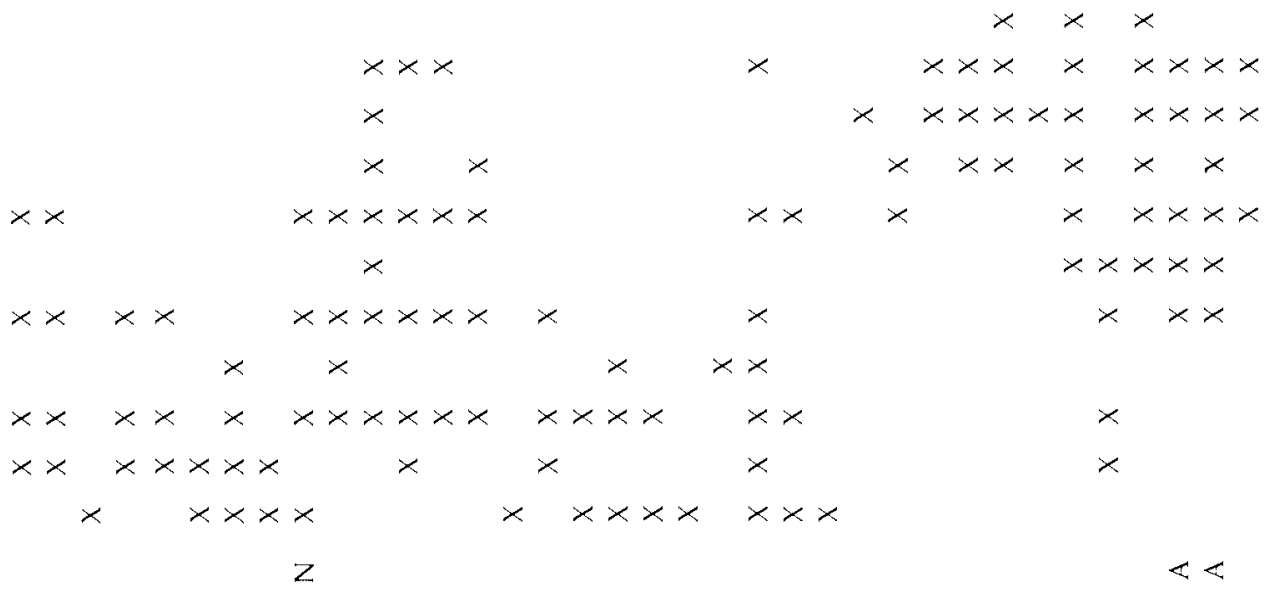

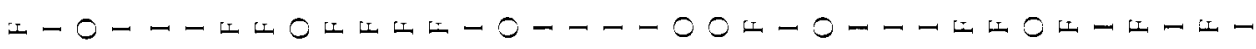

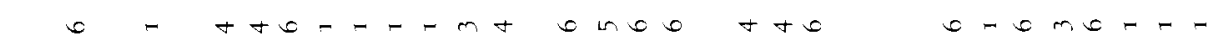

ヒ

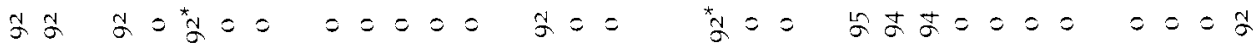
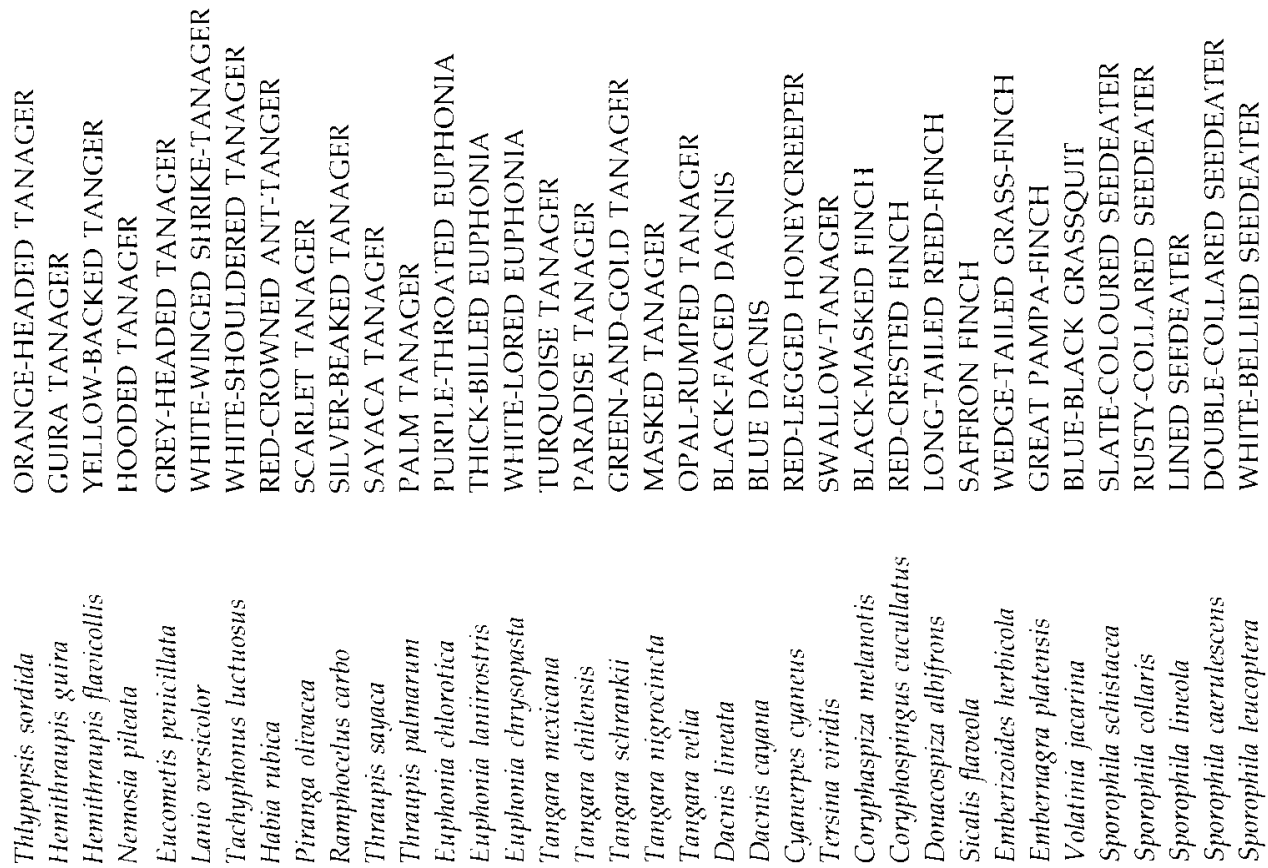


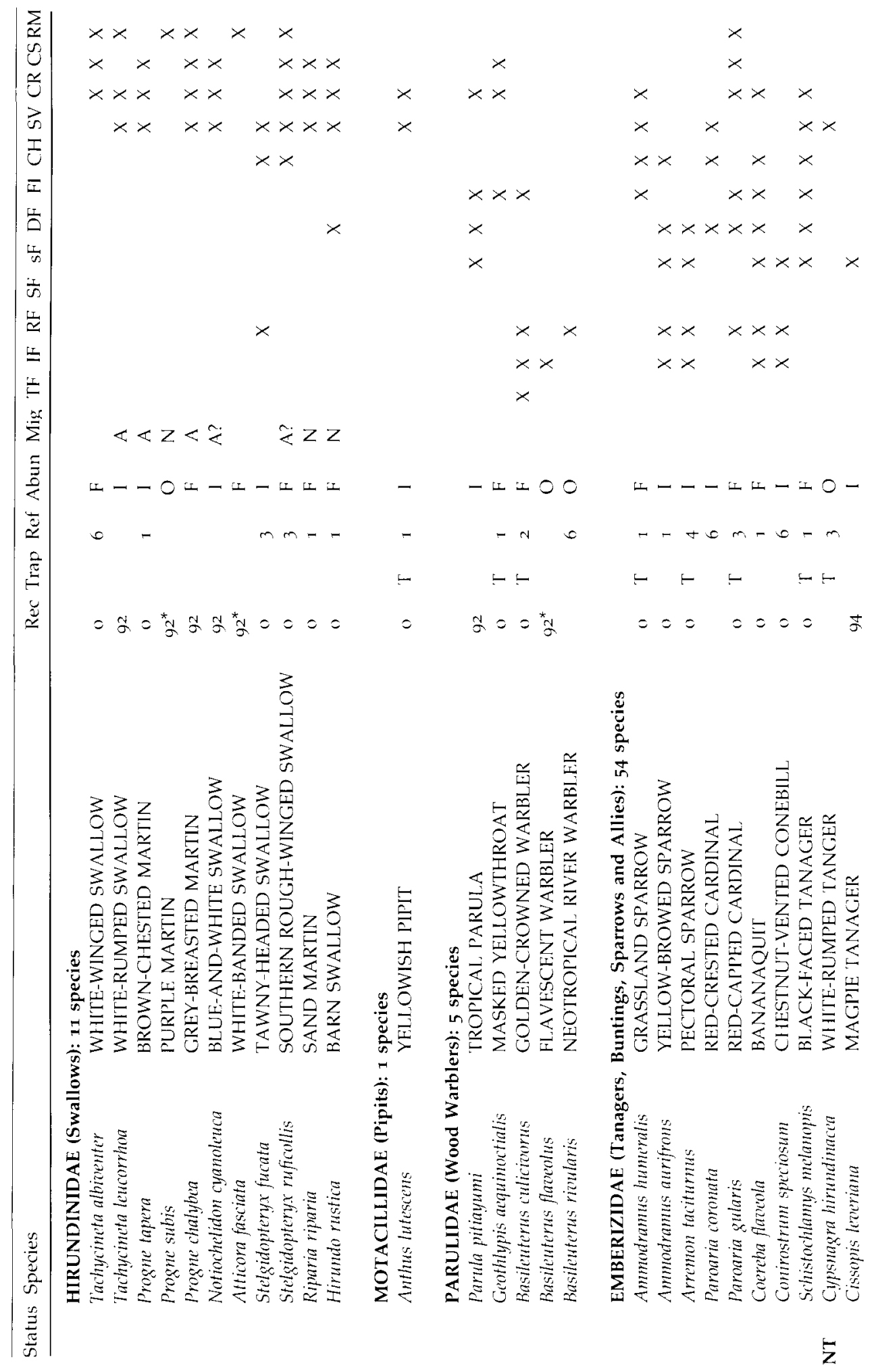



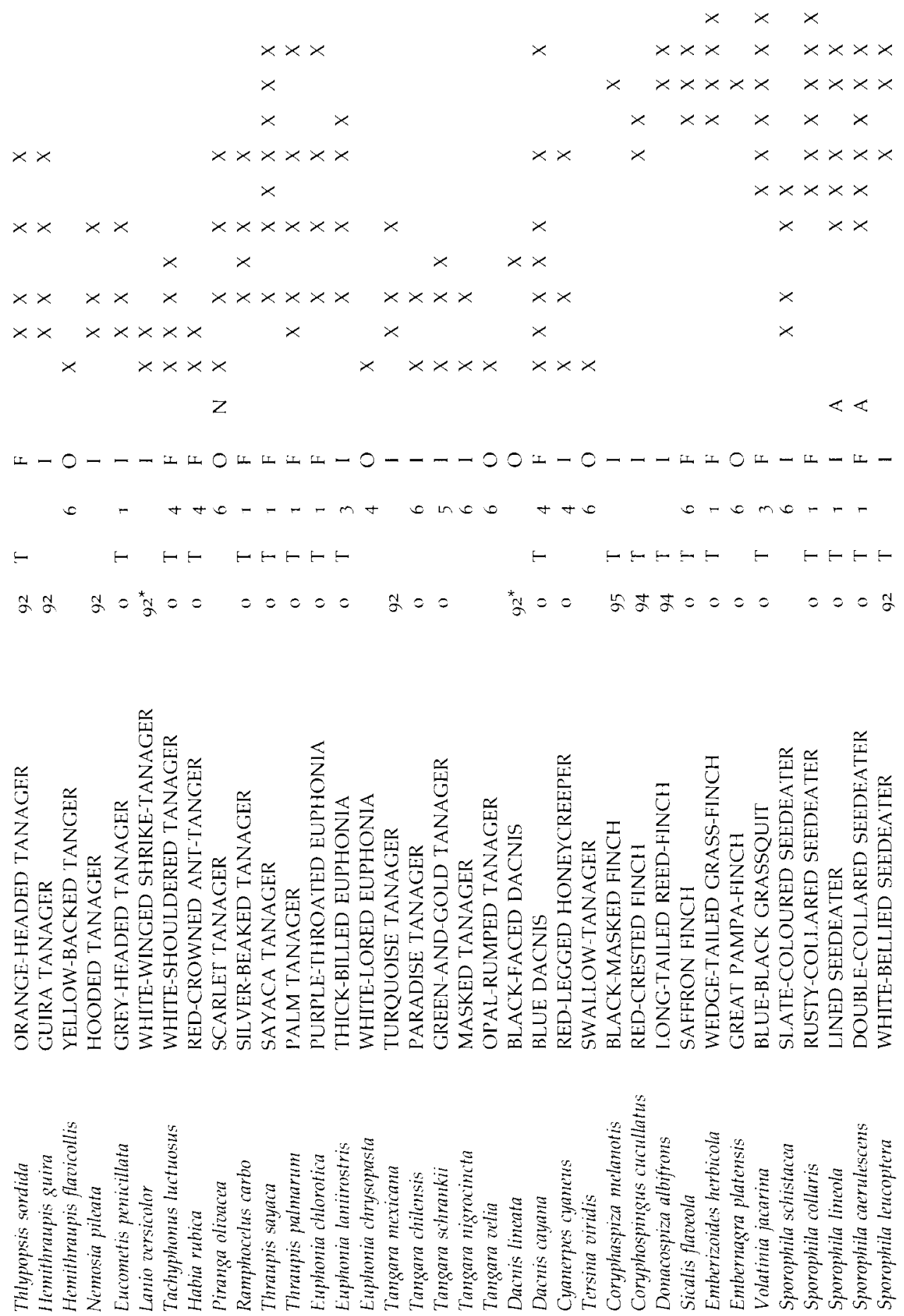


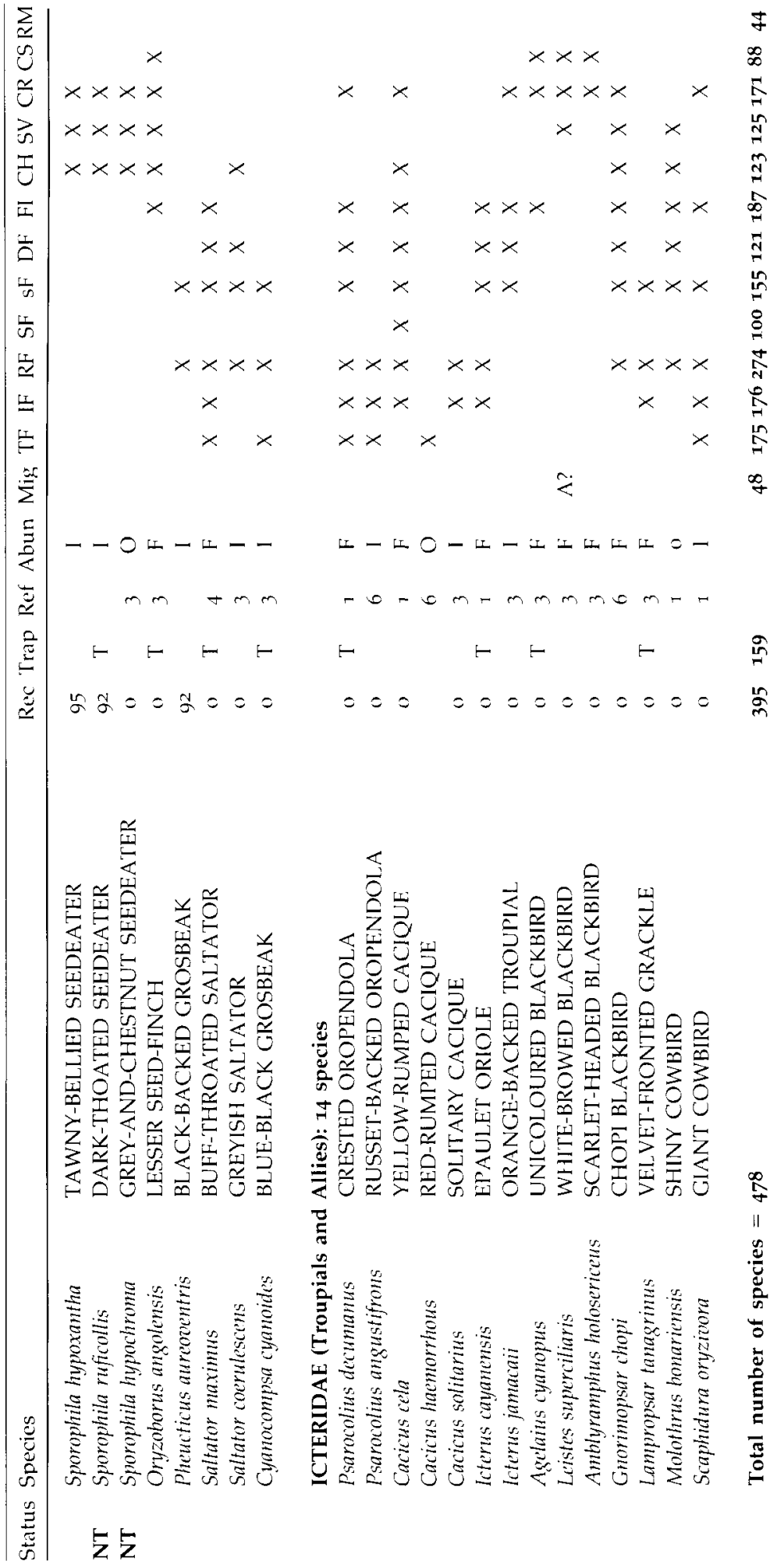




\section{Appendix 2. Species which have appeared in previous B.B.S lists, but which are not accepted.}

Species listed solely in Miranda et al. (1991).

1. Wattled Curassow Crax globlosa (THR - vulnerable). Although our extensive enquiries (S. Stab verbally 1992, White of al. 1993) have revealed probable sightings by Chimane Indians in terra firme forest $30 \mathrm{~km}$ south of the reserve, occurrence within the B.B.S. itself was not substantiated. Recent reports of the species come only from Brazil and Colombia (Collar et al. 1994).

2. Grey-bellied Goshawk Accipter poliogaster (NT). In the absence of specific documentation we reject records of this species, which is rare in lowland forest throughout its range (Collar and Andrew 1988).

3. Paint-billed Crake Neocex erythrops. In view of the fact that the distribution of this crake in Bolivia is little known (Remsen and Traylor, 1983, Parker and Rowlett 1984), we are not including it at this time. It was incorporated presumably on the basis of a non-specific reference to Neocrex sp. in Cabot et al. (1986).

4. Groove-billed Ani Crotophaga sulcirostris. The distribution of this species in South America does not encompass Bolivia (Sibley and Monroe 1990), and the entry refers obviously to Smooth-billed Ani Crotophaga ani.

5. White-bellied Spinetail Symallaxis propingua. The habitat was given as terra firme forest. Since this species is regarded an an obligate river-island occupant (Remsen and Parker 1983, Rosenberg 1990), records, which have come from terra firme forest, are regarded as highly suspicious. Its fragmented distribution encompasses Brazil, Colombia, Ecuador and Peru, but in Bolivia is known only from Pando (Río Beni) (Ridgely and Tudor 1994, Arribas et al. 1995).

6. Veery Cathorus fuscescens. There are few Bolivian records (Remsen and Ridgely 1980, Davis 1993), and therefore in the absence of specific documentation, it is not included here.

7. Yellow Warbler Dentroica petechia. Excluded for the same reason as Veery.

Those species which have appeared in other lists.

1. Solitary Eagle Harpuhaliaetus solitarius ( $\mathrm{NT}$ ). This bird was recorded by Cabot et al. (1986) as having been seen in both forests and savanna (very rare). However, since it inhabits usually the upper tropical zone (Remsen and Ridgely 1980, Remsen and Traylor 1989), it is presumed that these sightings relate to immature Crowned Eagle $H$. coronatus (with which it was at one time considered conspecific). Indeed, the first documented sighting for Beni of $H$. solitarius at $1050 \mathrm{~m}$ some $40 \mathrm{~km}$ west of San Borja, was quite recent (Parker 1989, Parker et al. 1991); elsewhere it is local in La Paz, Cochabamba, Santa Cruz and Chuquisaca (Arribas et al. 1995).

2. Orange-breasted Falcon Falco deirolencus (NT). Listed by White et al. (1993) on the basis of a sighting along the Rio Manique (TRC), the usual habitat of this species is foothills (see Cabot and Serrano 1986) and thus its occurrence at the B.B.S., where confusion with Bat Falcon Falco rufigularis Howell and Whitaker 1995) is possible, seems unlikely.

3. Azure Gallinule Porphymala flacirostris. Listed as questionable by Cabot et al. (1986).

4. Lesser Nighthawk Chordeiles acutipennis. The possibility of confusion with $C$. minor was not considered by White et al. (1993).

5. Ashy-tailed Swift Chaeturn andrei. Documentation necessary to eliminate other similar Chaetura spp. was not provided by White et al. (1993).

6. Rufous-throated Sapphire Hylocharis sapphinina. Previous inclusions of this hummingbird are attributable to Cabot et al. (1986). Since this species is virtually unknown in Bolivia (J. V. Remsen in litt.) it seems almost certain that confusion (re: $q$ H. sapphirina) with Gilded Hummingbird H. chrysura, which has similarly a rufous throat, was involved; thus we reject previous claims.

7. Stripe-chested Antwren Mymotherula longicauda. This species was recorded by White et al. (loc cit.), but the possibility of the trapped bird in question being Streaked Antwren $M$. surinamensis was not considered fully. Evaluation of this potential addition is still ongoing, however, with additional photographs supplied by A. G. White being studied currently.

8. Cocoa Thrush Turdus fumigatus. This species, which was listed by Cabot et al. (1986), Flores (1988) and Rocha (1990), is regarded here as Hauxwell's Thrush T. hauxarlli considered formerly as conspecific; it is doubtful whether $T$. fumigatus has been recorded from Bolivia (see Ridgely and Tudor 1989 for discussion). 
9. Carmiol's (Olive) Tanager Chlorothraupis carmioli. List by Rocha (1990) but not included in Miranda et al. (1991). This tanager is essentially an Andean foothill species (>500 m) (e.g. Schmitt and Schmitt 1987, Parker 1989) and seems unlikely to wander to lowland Beni. It is pertinent to note that immature Black-faced Tanagers Schistochlamys melnnovis (a species which is a widespread and common resident) are not dissimilar to $C$. carmioli in appearance.

\section{References}

Arribas, M. A., Jammes, L. and Sagot, F. (1995) Lista de las aves de Bolizia/A birdlist of Bolivia. Santa Cruz de la Sierra: Armonía.

Bibby, C. J., Collar, N. J., Crosby, M. J., Heath, M. F., Imboden, Ch., Johnson, T. H., Long, A. J., Stattersfield, A. J. and Thirgood, S. J. (1992a) Putting biodiversity on the map: priority areas for global conservation. Cambridge, U.K.: International Council for Bird Preservation.

Bibby, C. J., Hill, D. A. and Burgess, N. A. (1992b) Bird census techniques. London: Academic Press.

Bierregaard, R. O., Lovejoy, T. E., Kapos, V., Augusto dos Santos, A. and Hutchings, R. (1992) The biological dynamics of tropical rainforest fragments. Bioscience 42: 859-86.

Bierregaard, R. O. (1994) Long-winged Harrier. Pp. 138 in J. del Hoyo, A. Elliott and J. Sargatal, eds. Handbook of birds of the world, volume 2, New World vultures to guineafowl. Barcelona: Lynx Editions.

Blake, E. R. (1977) Manual of Neotropical birds, 1. Chicago: University of Chicago Press.

Brace, R. C., Barnard, C. J. and Hartley, J. C. (1995a) Earthcorps briefing: forest islands of Bolivia. Watertown, Mass.: Earthwatch.

Brace, R. C., Barnard, C. J. and Hartley, J. C. (1995b) Forest islands of Bolivia. Ground truth Earthwatch Research Report. Watertown, Mass.: Earthwatch.

Brace, R. C., Hesse, A. J. and White, A. G. (1995c) The endemic macaws of Bolivia. Cotinga 3: 27-30.

Brace, R. C., Hornbuckle, J. and Pearce-Higgins, J. W. (1996) Records of wintering Hudson's Black-tyrants at the Estación Biológica del Beni, Bolivia. Cotinga 5: 67-68.

Bucher, E. H. and Nores, M. (1988) Present status of birds in steppes and savannas of northern and central Argentina. Pp. $7^{1-79}$ in R. D. Goriup, ed. Ecology and conseriation of grassland birds. Cambridge, U.K.: International Council for Bird Preservation (Tech. Publ. 7).

Cabot, J. and Serrano, P. (1986) Data on the distribution of some species of raptors in Bolivia. Bull. Brit. Orn. Club. 106: 170-173.

Cabot, J., Serrano, P. Ibañez, C. and Braza, F. (1986) Lista preliminar de aves y mamiferos de la reserva "Estacion Biologica del Beni". Ecol. Bolivia 8: 37-44.

Canevari, M., Canevari, P., Carrizo, G. R., Harris, G., Mata J. R. and Staneck, R. J. (1991) Nueva guía de las aves Argentinas. Buenos Aires: Fundación Acindar.

Cavalcanti, R. B. (1988) Conservation of birds in the cerrado of central Brazil. Pp. 5966 in R. D. Goriup, ed. Ecology and conservation of grassland birds. Cambridge, U.K.: International Council for Bird Preservation (Tech. Publ. 7).

Clements, J. F. (1991) Birds of the world: a checklist, 4th Edn. Vista, Calif.: Ibis Publishing. Collar, N. J. and Andrew, P. (1988) Birds to watch: the ICBP world checklist of threatened birds. Cambridge: International Council for Bird Preservation (Tech. Publ. 8).

Collar, N. J., Gonzaga, L. P., Krabbe, N. Madroño Nieto, L. G., Parker, T. A. III and Wege, D. C. (1992) Threatened birds of the Americas: the ICBP/IUCN Red Data Book. Cambridge, U.K.: International Council for Bird Preservation.

Collar, N. J., Crosby, M. J. and Stattersfield, A. J. (1994) Birds to watch 2: the world list of threatened birds. Cambridge, U.K.: BirdLife International (BirdLife Conservation Series no. 4). 
Conservation International (1988) The Chimane Ecosystem Program, Bolivia. Washington, D.C: Conservation International.

Cracraft, J. (1985) Historical biogeography and patterns of differentiation within the South American avifauna: areas of endemism. Pp. 49-85 in P. A. Buckley, M. S. Foster, E. S. Morton, R. S. Ridgely and F. C. Buckley, eds. Neotropical ornithology. Washington, D.C.: American Ornithologist' Union (Orn. Monogr. 36).

Davis, S. E. (1993) Seasonal status, relative abundance and behavior of the birds of Concepción, Departamento Santa Cruz, Bolivia. Fieldiana Zool. n.s. 71: 1-33.

Davis, S. E. and Flores, E. (1994) First record of White-winged Nightjar Caprimulgus candicans for Bolivia. Bull. Brit. Orn. Club 114: $127^{-128}$.

Davis, S. E., Rocha O. Sarmiento, J. and Hannagarth, W. (1994) New departmental records and notes for some Bolivian birds. Bull. Brit. Orn. Clib 114: 73-85.

Denevan, W. M. (1966) The aboriginal cultural geography of the Llanos de Mojos of Bolivia. Los Angeles: University of California Press.

Dott, H. E. M. (1984) Range extensions, one new record, and notes on winter breeding of birds in Bolivia. Bull. Brit. Orn. Club 104: 104-109.

Dudley, L. C. C. (1992) The Chimane conservation program in Beni: an effort in local participation. Pp. 228-244, in K. H. Redford and C. Padoch, eds. Conservation of Neotropical forests. New York: Columbia University Press.

Flores, E. I. (1988) Perfil ornithologico de la reserva de la biosfera "Estacion Biologica Beni". Mus. Nal. Hist. Nat. (Bolivia) Communicación 8: 7-14.

Goriup, R. D., ed. (1988) Ecology and conservation of grassland birds. Cambridge, U.K.: International Council for Bird Preservation (Tech. Publ. 7).

Glydenstolphe, N. (1945) A contribution to the ornithology of northern Bolivia. Kungl. Sienska Vetenskapsakad. Handl. Ser. $323(1)$ : 1-300.

Haffer, J. (1985) Avian zoogeography of the Neotropical lowlands. Pp. 113-145 in P. A. Buckley, M. S. Foster, E. S. Morton, R. S. Ridgely and F. C. Buckley, eds. Neotropical ornithology. Washington, D.C.: American Ornithologist' Union (Orn. Monogr. 36).

Howell, S. N. G. and Whittaker, A. (1995) Field identification of Orange-breasted and Bat falcons. Cotinga 4: 36-43.

IUCN (1992) Protected areas of the world: a review of national systems. Volume 4: Nearctic and Neotropical. Gland, Switzerland, and Cambridge, U.K.: International Union for Conservation of Nature and Natural Resources.

Jordan, O. C. and Munn, C. H (1993) First observations of the Blue-throated Macaw in Bolivia. Wilson Bull, 105: 694-695.

Karr, J. (1981) Surveying birds in the tropics. Stud. Avian Biol. 6: 548-553.

Killeen, T. J., Louman B. T. and Grimwood, T. (1990) La ecologia paisajística de la región de Concepción y Lomerío en la Prov. Nuflo de Chávez, Santa Cruz, Bolivia. Ecol. Bolivia 16: 1-45.

Killeen, T. J., Garcia, E. and Beck, S. G., eds (1993) Guia de arboles de Bolivia. La Paz, Bolivia: Herbario Nacional de Bolivia and Missouri Botanical Garden.

Kratter, A. W., Sillett, T. S., Chesser, R. T., O'Neill, J. P., Parker, T. A., III and Castillo, A. (1993) Avifauna of a chaco locality in Bolivia. Wilson Bull. 105: 114-141.

Lowen, J. C., Bartrina, L., Brooks, T. M., Clay, R. P. and Tobias, J. (1996) Project Yacutinga '95: bird surveys and conservation priorities in eastern Paraguay. Cotinga 5: $14-19$.

MacArthur, R. H. and Wilson, E. O. (1967) The theory of island biogeography. Princeton: Princeton University Press.

Miranda, C., Ribera, M. O., Sarmiento, J., Salinas, E. and Navia, C., eds. (1991) Plan de manejo de la reserva de la biosfera, Estación Biológica del Beni, 1991. Academia Nacional de Ciencias de Bolivia/Estación Biológica del Beni.

Monroe, B. L. and Sibley, C. G. (1993) A world checklist of birds. New Haven, Conn.: Yale University Press. 
Negret, A. and Teixeira, D. M. (1984) The Ocellated Crake (Micropygin schomburgkii) of central Brazil. Condor 86: 220.

Nores, M. (1992) Bird speciation in subtropical South America in relation to forest expansion and retraction. Auk 199: 346-357.

Parker, T. A., III and Rowlett, R. A. (1984) Some noteworthy records of birds from Bolivia. Bull Brit. Onn. Club 104: 110-113.

Parker, T. A., III (1989) An avifaunal survey of the Chimane ecosystem program area of northern Bolivia, 17-26 June 1989. Unpublished report (for Conservation International).

Parker, T. A., III, Castillo, A., Gell-Mann, G. and Rocha, O. (1991) Records of new and unusual birds from northern Bolivia. Bull. Brit. Orn. Club 111: 120-138.

Parker, T. A., III and Rocha, O. (1991) La avifauna del Cerro San Simón, una localidad de campo rupestre aislado en el depto. Beni, noreste Boliviano. Ecol. Bolivia 17: 15-29.

Pearce-Higgins, J. W. (1996) Seedeaters in the Noel Kempff Mercado National Park, Bolivia. Cotinga 5: 69-71.

Pearson, D. L. (1975) Range extensions and new records for bird species in Ecuador, Peru and Bolivia. Condor 77: 96-99.

Remsen, J. V., Jr and Ridgely, R. S. (1980) Additions to the avifauna of Bolivia. Condor 82: $69-75$.

Remsen, J. V., Jr and Parker, T. A., III (1983) Contribution of river-created habitats to bird species richness in Amazonia. Biotropica 15: 223-231.

Remsen J. V., Jr and Traylor, M. A., Jr (1983) Additions to the avifauna of Bolivia. Part 2. Condor 85: 95-98.

Remsen, J. V., Jr (1986) Aves de una localidad en la sabana húmeda del norte de Bolivia. Ecol. Bolivia 8: 21-35.

Remsen, J. V., Jr, Traylor, M. A., Jr and Parkes, K. C. (1986) Range extensions for some Bolivian birds, 2 (Columbidae to Rhinocryptidae). Bull. Brit. Orn. Club 106: 22-32.

Remsen, J. V., Jr and Traylor, M. A. Jr (1989) An annotated list of the birts of Bolizia. Vermillion, S.D.: Buteo Books.

Remsen, J. V., Jr and Parker, T. A., III (1995) Bolivia has the opportunity to create the planet's richest park for terrestrial biota. Bird Conserv, Int. 5: 181-199.

Ridgely, R. S. and Tudor, G. (1989) The birds of South America, 1: the oscine passerines. Austin, Tex.: University of Texas Press.

Ridgely, R. S. and Tudor, G. (1994) The birds of South America, 2: the subosine prasserines. Austin, Tex.: University of Texas Press.

Rocha, O. (1988) Adicion de especies a la avifauna de la reserva de la biosfera "Estación Biológica del Beni", Bolivia. Ecol. Bolivia 12: 13-15.

Rocha, O. (1990) Lista preliminar de aves de la reserva de la biosfera "Estación Biológica del Beni". Ecol. Bolizia 15: 57-68.

Rocha, O. and Peñaranda, E. (1992) Habitos alimenticios de cuatro especies de trepatroncos (Aves, Dendrocolaptidae) de la reserva de la biosfera "Estacion Biologica del Beni" (Beni, Bolivia). Ecol. Bolizia 19: 57-72.

Rosenberg, G. H. (1990) Habitat specialization and foraging behaviour by birds of Amazonian river islands in northeastern Peru. Condor 93: 427-443.

Schmitt, C. G. and Schmitt, D. C. (1987) Extensions of range of some Bolivian birds. Bull. Brit. Orn. Club 107: 129-134.

Scott, D. A. and Carbonell, M. (1986) A directory of Neotropical wetlands. Cambridge, U.K.: International Union for Conservation of Nature and Natural Resources, and Slimbridge, U.K.: International Waterfowl Research Bureau.

Sibley, C. G. and Monroe, B. L. Jr (1990) Distribution and taxonomy of birds of the curld. New Haven, Conn.: Yale University Press.

Stotz, D. F., Fitzpatrick, J. W., Parker, T. A., III and Moskovits, D. K. (1996) Neotropical birds: ecology and conseriation. Chicago: The University of Chicago Press. 
Wege, D. C. and Long, A. J. (1995) Key areas for threntened birds in the Neotropics. Cambridge, U.K.: BirdLife International (BirdLife Conservation Series no. 5).

Willis, E. O. and Oniki, Y. (1988) Bird conservation in open vegetation of São Paulo state, Brazil. Pp. 67-70 in R. D. Goriup, ed. Ecology and conservation of grassland birds. Cambridge, U.K.: International Council for Bird Preservation (Tech. Publ. 7).

White, A. G., Brace, R. C., Duffield, G. E., Hesse, A. Payne, A. J. and Spick, S. (1993) Nottingham University Bolivia Project 1992: an ornithological survey of the Beni Biological Station. Unpublished report (for BirdLife International).

White, A. G., Brace, R. C. and Payne, A. J. (1995) Additional records of and notes on the Unicoloured Thrush Turdus haplochrous, a little known Bolivian endemic. Bull. Brit. Orn. Club 115: 29-33.

\section{ROBIN C. BRACE}

Department of Life Science, University of Nottingham, University Park, Nottingham NG7 2RD, U.K. e-mail: plarcba pln1.life.nottingham.ac.uk

\section{JON HORNBUCKLE}

3o Hartington Road, Sheffield $S_{7} 2 L F, U . K$.

\section{JAMES W. PEARCE-HIGGINS}

3.239 Stopford Building, School of Biological Sciences, The University of Manchester, Oxford Road, Manchester M13,PPT, U.K.e-mail: moenejup@fs2.scg.man.ac.uk 